Atıf: Çetinkaya, S.C., Göközkut, B. (2021). Ulusötesi Bir Mekânın Boşnak Kolektif Belleği ile Yaratım Süreci ve Kimliğin Mekânsal Sunumu: İstanbul-Yıldırım Mahallesi, Coğrafi Bilimler Dergisi/Turkish Journal of Geographical Sciences, 19(1), 61-91, doi: 10.33688/aucbd.836348

Coğrafi Bilimler Dergisi

Turkish Journal of Geographical Sciences

e-ISSN:1308-9765

\title{
Ulusötesi Bir Mekânın Boşnak Kolektif Belleği ile Yaratım Süreci ve Kimliğin Mekânsal Sunumu: İstanbul-Yıldırım Mahallesi
}

\author{
The Process of Creation with the Bosnian Collective Memory of a Transnational \\ Space and Spatial Presentation of Identity: Istanbul-Yildırım District
}

Sibel Can Çetinkaya*a, Burcu Göközkut ${ }^{\text {b }}$

\begin{tabular}{l} 
Makale Bilgisi \\
\hline Araştırma Makalesi \\
\hline DOI: \\
10.33688/aucbd.836348 \\
\hline Makale Geçişi: \\
Geliş: 05.12.2020 \\
Kabul: 11.03.2021 \\
\hline Anahtar Kelimeler: \\
Ulusötesi Göç \\
Ulusötesi Mekân \\
Kolektif Bellek \\
Boşnak \\
Y1ldrım Mahallesi \\
\\
\\
\hline Article Info \\
\hline Research Article \\
\hline DOI: \\
10.33688/aucbd.836348 \\
\hline Article History: \\
Received: 05.12.2020 \\
Accepted: 11.03.2021 \\
\hline Keywords: \\
Transnational Migration \\
Transnational Space \\
Collective Memory \\
Bosniaks \\
Y1ldırım Neighbourhood \\
\hline
\end{tabular}

$\ddot{O} z$

Bu çalışmada, Boşnak kolektif belleğinin ulusötesi sosyal mekânların oluşum sürecini nasıl etkilediği ve kimliğin mekânlarda nasıl temsil edildiği incelenmiştir. Bu süreçte, araştırma alanı olarak, göçlerle birlikte gelişen ve Boşnak kimliği ile özdeşleşen Yıldırım Mahallesi tercih edilmiştir. Çalışmada, nitel araştırma yöntemi kullanılmıştır. Kartopu örnekleme tekniği kullanılarak; derinlemesine görüşmeler ve odak grup görüşmeleri yapılmıştır. Elde edilen bulgular betimsel analiz yöntemi kullanılarak analiz edilmiştir. Çalışmada, Boşnak göçmenlerin Yıldırım Mahallesi'ni tarım arazisinden ulusaşırı sosyal bir mekâna dönüş̧ürdüğü anlaşılmıştır. Bu alan, Boşnakların sosyo-kültürel pratikleri ile şekillenirken, kimliğinin sembolleri ile donatılarak adlandırılmış ve böylece bir şekilde kimliğin sürekliliği sağlanmıştır. Sonuç olarak, üretilen mekânlar bireylerin iki ülkeye aidiyet bağı geliştirmelerinde etkili olmuştur.

\begin{abstract}
In this study, we examined how Bosniak collective memory affects the process of formation of transnational social spaces and how identity is represented in spaces. In this process, the Ylldirtm Neighbourhood, which developed with migrations as a research area and identified with its Bosniak identity, was preferred. Qualitative research methods were used in the study. Using the snowball sampling technique, in-depth interviews and focus group interviews were conducted. The findings were analyzed using the descriptive analysis method. The study understood that Bosniak immigrants transformed Yildırım Neighbourhood from farmland into a transnational social space. While this area was shaped by the socio-cultural practices of Bosniaks, it was named by equipping it with symbols of its identity, thus providing continuity of identity in some way. As a result, the spaces produced were effective in developing a bond of belonging to the two countries.
\end{abstract}

\footnotetext{
*Sorumlu Yazar/Corresponding Author: sibelcancetinkayaa@gmail.com

a Afyon Kocatepe Üniversitesi, Sosyal Bilimler Enstitüsü, Coğrafya Anabilim Dalı, Afyonkarahisar/Türkiye, https://orcid. org/0000 -0002-5931-1925.

bAfyon Kocatepe Üniversitesi, Fen Edebiyat Fakültesi, Coğrafya Bölümü, Afyonkarahisar/Türkiye, https://orcid.org/00000002-2214-8327.
} 


\section{Giriș}

Geçmiş, uzamda somut olarak var mıdır?

Geçmişin varlı̆̆ını hala koruduğu herhangi bir yer, bir somut nesneler dünyası var mıdır?

Orwell, 2019: 268

Günümüzde küreselleşme ile mesafeler ve sınırlar bulanıklaşmıştır. İnsan hareketliliği zamansal ve mekânsal sınırları aşarak kozmopolit coğrafyalar ve mekânlar oluşturmuştur. Küreselleşme ile gerçekleşen bu hareketlilik nüfusun dağılışını değiştirirken yeni sosyo-mekânsal süreçlerin doğuşuna öncülük etmiştir. Zamansal akışkanlık, beraberinde mekânsal ve toplumsal akışkanlığı getirmiştir. Özellikle, iletişim ve ulaşım teknolojilerinin hızla gelişmesi ve erişim olanağının artması, göçmenlerin geldikleri yerlerle yakın ilişkilerini sürdürmesini gittikçe daha da kolaylaştırmıştır (Vertovec, 2004). Sermayenin ve üretimin farklı coğrafyalara yayılması, emeğin sermayeyi, sermayenin emeği takip etmesi, demografik hareketliliği artırarak sınırların aşımını kolaylaştırmış, sınır aşırı sirkülasyonu hızlandırmıştır. Özellikle, iktidar ve ekonomik politikalarda yaşanılan değişimler; liberal ekonomik ilkelerin ve sosyal ilkelerin alanını genişletmesini sağlarken, makro düzeydeki işlevsel sistemleri ve bu sistemlerde yer alan organizasyonların pozisyonları; bireyler arasında mikro etkileşimin karakterinde değişikliklere yol açmıştır (Bruneau, 2010; Castles, 2002, 2010; Castles ve Miller, 2008) Bu durum, aynı zamanda insanların ekonomik, sosyal ya da kültürel bağlarının olduğu birtakım yerler arasında düzenli olarak göç etmelerinde olduğu gibi, tekrarlanan göç hareketlerini ve dolaşımın büyüklüğünü arttırmıştır (Castles ve Miller, 2008: 40). Bu sayede insan hareketliliği önemli ölçüde arttığı ve uluslararası iletişim kolaylaştığı için birçok bireyin gündelik yaşamları yalnızca tek bir coğrafi lokasyona bağlı kalmaktan kurtulmuş (Özgür, 2018: 9), çoklu mekânsal yaşamlar toplumların fiziki çevreleriyle yarattığı etkileşiminin ortaya çıkardığı yeryüzünün farklılaşmasını sağlayarak önemli değişmeler yaratmıştır (Tekeli, 2010: 74). Tüm bunlar, göçmenlerin menşe ülke ile bağlarını koparttıkları algısını değiştirmiştir. Artık göçmenler; menşe ve ev sahibi topluma eş zamanlı katılan, farklı alanları birbirine bağlayan, sınır aşırı ağlar oluşturan, toplumları dönüştüren ve süreç içerisinde aktif rol oynayan bireyler olarak tanımlanmaya başlanmıştır (Glick-Schiller, 1992: Özgür, 2018). Glick-Schiller vd. (1992), ulusötesiciliği bir kavram haline getirmenin, tek bir sosyal ve ekonomik sistem olan dünyanın farklı kısımlarında meydana gelen göç tecrübesini, yeni oluşumlarını ve belirtilerini anlamamıza izin verdiğini belirtmektedir.

Ulusötesi göç çalışmaları, göçmenlerin günlük hayat içerisinde menşe ve ev sahibi toplum ile ilişkilerine, göçmenlerin birçok yer ile oluşturdukları ekonomik, politik ve sosyo-kültürel sınır aşırı ağlara odaklanır (Faist, 2012; Glick-Schiller vd., 1992; Levitt ve Jaworsky, 2007; Özgür, 2018). Bu ağların kurulup geliştiği alanlar; göçmenlerin ekonomik, politik ve sosyo-kültürel pratiklerini gerçekleştirdiği toplumsal değişimin yaşandığı çok katmanlı ilişkilerin geliştiği alanlardır. Bu alanlar, farklı yerlerdeki insanlar, ağlar ve örgütler arasında, verili ülke sınırları ötesine geçen ilişkiler kurulmasına olanak sağlamaktadır (Faist, 2003: 16). Bu alanlar aynı zamanda, göçmenlerin var olma ve ait olma yollarının oluştuğu, sosyo-mekânsal aidiyet ve kimlik duygularının üretildiği alanlardır. Bu süreçte göçmenlerin var olma yolları, göçmenlerin günlük sosyal ilişkilerini içerirken, ait olma yolları ise bu ilişkiler içerisinde insanların bilinçli bir şekilde sadakat ilişkileri geliştirmesini vurgulamaktadır (Glick-Schiller, 2003 akt. Özkul, 2006: 493). Bu ilişkiler içerisinde göçmenler, menşe bölgeyi temel alan kültürel ve 
dini özelliklere dayanan ortak kimlik algısını paylaşırlar (Vertovec, 2001). Göçmenlerin kimlikleri, ilişkiler geliştirdiği alanlarda sürekli olarak müzakereye açıktır. Bu süreçte, gönderen toplumun kurumları ve alıcı toplumun politikaları; göçmenlerin her iki topluma katılım sürecini ve kimliklerini inşa etme ve sürdürme yollarını etkiler. Kimliğin ulusaşırı alanda tezahürü, göçmenlerin günlük hayat içerisindeki eylemlerinde ve ilişki kurdukları mekânlarda kendini çeşitli formlarda gösterebilir. Göçmenlerin yerleştiği alanlarda kendilerini güvende hissetmeleri ve uzun süre yaşamaları o yere bağlanmalarını, aynı zamanda kimliklerini ve kolektif belleklerini mekânla buluşturmalarını sağlamaktadır. Özellikle bu durum, hareketli göçmen gruplarının yaşadıkları ulusötesi mekânlarda belirginleşmektedir. Bu bireyler ulusötesi mekânlar arasında oluşturdukları ağlarda kültürlerini taşıyarak ulusötesi sosyal alanlar içerisinde kimliklerini inşa ederler ve yeniden üretirler (Yazgan, 2016: 289). Bu mekânlarda kimliğin inşa edilerek aidiyetlik duygusunun sürdürülmesinde belleğin rolü önemlidir. Bellek, ulusötesi mekânda bireyin kimliğini yerel karşılaşmalarla birlikte inşa etmesine yardımcı olur, ikili bir aidiyetlik bilincinin oluşmasını sağlar. Bu bilince sahip bireyler en az iki ülke arasında çeşitli ağlarda hareket edebilir. Bu hareketliliğin sürdürülmesi göçmen topluluklarına ve bir sonraki neslin tutumlarına göre değişkenlik göstermektedir.

Bu çalışma, 1952-1967 yılları arasında Yugoslavya'dan Türkiye'ye göç eden Boşnakların kolektif belleği tarafından üretilmiş bir kimlik mekânına odaklanmaktadır. Bu bağlamda İstanbul Bayrampaşa ilçesinde bulunan Yıldırım Mahallesi ve bu mahallenin şekillenmesinde büyük rol oynayan Boşnaklar incelenmiştir. Boşnaklar, bu alanı iki ulus devlet arasında ulusaşırı ağları ile ulusötesi sosyal bir mekâna dönüştürerek sosyo-kültürel faaliyetlerde bulunurlar. Bu nedenle çalışmanın temel amac1, Y11dırım Mahallesi'nde Boşnak kolektif belleği ile üretilen mekânlarda kimliğin temsil edilme biçiminin ne/nasıl olduğunun sorgulanmasıdır. İlçede yaşayan göçmenler ile ilgili yapılan çalışmalar (Bozkurt, 2012; Celep, 2019; Davutoğlu, 2010; Dural, 2016; Erman, 2019; Eseler, 2016; Güler, 2013; Sözer Dabanlığlu, 2018; Tekinkaya, 2015; Yanardağ, 2009; Yıldız, 2019) arasında Boşnak kimliğinin sürdürülmesinde kolektif belleğin mekân ile ilişkisi ele alınmamıştır. Önceki ilgili çalışmalarda; menşe ülke ve ev sahibi ülke ile aralarında oluşturulan ağların özellikleri, bu ağların oluşma süreçleri ve bu süreçleri etkileyen yapılar araştırılmaktadır. Bazı çalışmalar; ev sahibi toplum ve menşe toplum arasında kurulan ekonomik ağların yapısını (para havaleleri ve bu havalelerin gönderilen bölgelerde nasıl kullanıldığı, kalkınma üzerine etkisi bu bağlamda devletlerin geliştirdiği politikalar) (Guarnizo, 1997), politik ağları (vatandaşlık politikaları, menşe toplumda oy kullanma, siyasal partilere üyelik, lobi faaliyetleri, yerleşilen toplumda dernekler kurma, siyasal eylemler de bulunarak hem ev sahibi hem de geride kalan topluma siyasi açıdan etkisi) (Baubök, 2003; Levitt ve Jaworsky, 2007), dini ağları (bu ağların, tek bir toplumun dışında farklı bölgelerde yaşayan aynı dini mensup bireyleri etkilediği) sosyo-kültürel ağları (sosyal sermayeleri, düşünceler, davranışlar, sembollerin çift yönlü iletimi) (Levitt, 1998) ve ulusaşırı göçmenlerin kimliklerini nasıl inşa ettiği ve aidiyet bağlarını nasıl oluşturdukları araştırılmıştır. Oysa göçmenlerin menşe toplum ve ev sahibi topluma aidiyet bağı geliştirmesinde kolektif hafiza ve mekânın ilişkisi önemlidir. Bu çalışmada, göçmenlerin kolektif belleği ile üretilen mekânların kimliğin sürdürülmesinde ve aidiyet bağının gelişmesinde katkısının olduğu ortaya koyulmaya çalışılmıştır. Çalışmada, Boşnakların ulusötesi sosyal alandaki faaliyetleri, sosyo-kültürel pratikleriyle sınırlandırılmıştır. Sosyo- 
kültürel pratikleri; yıl içinde her yıl yapmış oldukları ziyaretler, yöresel lezzetlerin diğer ülkeden taşınması, ayrıca birtakım işletmelerde menşe bölgeden getirilen ürünlerin sunulması, memleket dernekleri aracıllğıyla yaptıkları anma etkinlikleri, kültür günleri, seminerler, sosyal yardımlar ve kamuoyu açıklamaları ile sınırlandırılmıştır. Çalışmada, Yıldırım Mahallesi'nin tarım arazisinden ulusötesi sosyal bir mekâna dönüşme sürecini, yerel toplumda ötekileştirilme sürecini ve daha sonra mekânların Boşnak kolektif belleği ile üretilmesini ve kimliğin mekândaki sunumu üzerinde durulmuştur.

\section{Ulusötesi Mekânlar ve Kolektif Bellek}

Ulusötesi teorinin uluslararası göç yazınında önemli bir teorik çerçeve olarak ilgi görmesi 1990'ların sonlarına doğru hızla ilerlemiştir (Al-Ali vd., 2001). Ulusötesi/Ulusaşırı, göçmenlerin menşe ülkelerini ve yerleşilen ülkeleri birbirine bağladıkları ve çoklu kimlikler kullandıkları sosyal alanlar inşa etme süreci olarak ifade edilmektedir (Glick- Schiller vd., 1992; Guarnizo, 1997). Bu süreç içerisinde ulusaşırı göç literatürü genişledikçe "ulusötesi topluluk" kavramı sıklıkla kullanılmaya başlanmıştır (Bruneau, 2010). Ulusötesi göçmenler/topluluklar; gündelik hayatları ulusal sınırları aşan, en az iki ülke arasında sosyal, ekonomik, politik ve dini ilişkiler geliştiren göçmenlerdir (Bowen, 2004; Castles, 2002; Faist, 2000; Glick -Schiller vd., 1992; Guarnizo, 1997; Kivisto, 2001; Levitt, 1998, 2003; Özgür, 2018; Portes, 2000; Şimşek, 2019). Ulusötesi göçmenler; geride bıraktıkları ülkeler ile işçi dövizleri/para havaleleri yoluyla ekonomik ilişkilerini sürdüren (Cohen, 2019; Guarnizo, 1997, 2003; Vertovec, 2004) girişimcilik faaliyetleri ile en az iki ülkenin yerel ve uluslararası piyasasına eklemlenen (Guarnizo, 2003; Honig, 2019; Nkrumah, 2017) sosyal havaleler yoluyla iki toplumun sosyo-kültürel alanını etkileyen (Levitt, 1998; Levitt ve Lamba-Nieves, 2011; Vertovec, 2004) ve politik faaliyetlerde bulunan göçmenlerdir. Ulusötesi sosyal mekânlar/alanlar ise hareketli ve yerleşik toplumların; en az iki ülke arasında çeşitli ağlar geliştirdiği ve bu ağlarda ekonomik, politik ve kültürel sermayelerini kullanarak yeni sermaye türlerinin üretildiği; aidiyetliğin ve kimliğin sürdürülerek yeni aidiyetlik, sınıf, kimlik ve politikaların geliştirildiği; siyasi eylemlerin yapıldığı, demografinin ve toplumsal cinsiyet ilişkilerinin değiştiği ve çeşitli iktidar yapılarının gömülü olduğu arenalardır (Bruneau, 2010; Collyer ve King, 2014; Crang vd., 2003; Dannecker, 2005; Faist, 2000, 2003, 2012; Fouron ve Glick-Schiller, 2001; Levitt ve GlickSchiller, 2004; Levitt ve Jaworsky, 2007; Özgür, 2018; Şimşek, 2019; Voigt-Graf, 2004). Bu alanlar, en az iki ülke arasında hareket eden ve geride kalanları birbirine bağlayan, hareketli ve yerleşik bireylerin çeşitli iletişim biçimleri sayesinde sürdürülen, ulusal sınırları aşan sosyal, ekonomik ve politik ilişkilerin analizini sağlar (Levitt ve Glick- Schiller, 2004).

Ulusötesi sosyal mekânların üretimi ve hareketliliğin yapısı, ev sahibi toplumun ve geride kalan toplumun tarihi ve siyasi faaliyetleri gibi yapısal koşullar tarafından etkilenir (Al-Ali vd., 2001; Massey vd., 1994). Ayrıca devletlerin ulusötesi politikaları, göçmenlerin hareketliliğini ve yereldeki yaşam biçimlerini etkilemektedir. Bu durum, küresel ve yerelin iç içe olduğunu ve karş1lıklı olarak birbirlerini yapılandırarak yeniden ürettiklerini göstermektedir (Glick-Schiller ve Çağlar, 2009; Ley, 2004). Göçmenlerin ilişkileri; gönderilen dövizler, sosyal havaleler ve politik katılım üzerinden incelenir. Bunlar, göçmenlerin menşe topluma sadakatlerinin bir göstergesidir. Oysa süreci başlatan ve sürmesini sağlayan, göçmenlerin aidiyet duygularıdır. Süreç ilerledikçe alıcı topluluğun yerel ortamları dönüştürülerek 
(Massey vd., 1994) yerel toplum içerisinde yeni aidiyet biçimleri üretilir. Bu üretim sürecinde göçmenlerin sınıf, cinsiyet ve etnik özellikleri ev sahibi topluma kabul sürecini ve mekânların üretim sürecini etkilemekle birlikte yerleşilen mekânların şekillenmesinde de etkendirler. Aidiyet bağlarının oluştuğu ve geliştiği mekânlar, bireyler için anlam dünyalarını inşa ettikleri bir yere dönüşür. Özellikle yerler, göçmenlerin kimliklerini inşa etmelerinde, sürdürmelerinde ve dönüştürmelerinde önemli bir çerçeve sağlamasının yanı sıra aynı zamanda sosyal kimliklerini iletmelerini ve sosyal kimlikleri aracılığıyla alanı anlamlı yerlere dönüştürmelerini ve yorumlamalarını sağlamaktadır (Cuba ve Hummon, 1993; Hopkins ve Dixon, 2006). Böylece gidilen yeni bölgelerde bireyler, kimliklerinin çatısı altında toplanarak mekânsal düzenlemelerle birlikte yer duygusu kazanmaya ve bir aidiyet alanı oluşturmaya çalışırlar. $\mathrm{Bu}$ süreçte, özellikle mekânsal üretimin her parçasına dâhil olan bireyler çevreyle birlikte kendilerini dönüştürmekte kimliklerini ve köken bölgeye dair anlatılarını ise mekânsallaştırma eğilimindedirler. Harvey (2015: 207), yerler inşa ederken (ev gibi) kendimizi inşa ettiğimizi, dolayısıyla içinde bulunduğumuz yerlere durmadan yeniden şekil verdiğimizi, bu yeniden şekil verme işini hem maddi hem kavramsal düzeylerde yaptığımıza değinirken, aynı zamanda o yerde nasıl yaşadığımızın mekânı ne şekilde ürettiğimiz -inşa ettiğimiz- ile ilişkili olduğundan söz eder. Castells (2006), bu inşa sürecinin kültürel olduğunu yani anlamları ve paylaşımları belli öz tanımlama kodlarıyla, başka bir deyişle inananlar cemaati, milliyetçilik ikonları, yerelliğin coğrafyasıyla damgalanmış bir değerler kümesi etrafında örgütlendiklerini belirtir. "Sembolik ve pratik bileşenleriyle üretilen mekânlar, aynı zamanda kendisini ilgilendiren mit ve öykülerin taşıyıcısıdır, üretilmiş mekânlarda edimler 'kimse' farkına varmasa bile anlamı yeniden üretir. Bu kodlar da bir topluma aittir ve bir aidiyeti şart koşar (Lefebvre, 2015: 208-164228)". Bu üretim sırasında insanlar, mekâna sırlarını iliştirirler, bilinenleri bilinmeyen, görünenleri görünmeyen, görünmeyenleri ise görünen yaparak mahremiyet ve kamusallık arasında sosyo-mekânsal dünyalarına özgü anlamlar üretirler. Bu süreçte, göçmenler kaynak bölge ile aralarında yaşanılan kesintinin giderilmesine ihtiyaç duyarlar. Bu ihtiyaç bellek tarafından karşılanır. Dolayısıyla bellek; muğlaklık, bulanıklık karşısında Boyer'in belirttiği gibi şimşek gibi çakmalı, insanların geleceğe doğru ilerlerken tutacakları yolu görebilmeleri için dünyanın o belirli andaki düzenini göstermeye çalışmalıdır (Boyer, 1996: 135 akt. Harvey, 2015: 211).

Ulusötesi mekânlarda, menşe toplum ile aidiyet bağlarının korunmasında ve ev sahibi toplum ile aidiyet bağlarının oluşmasında bir grup kimliği olarak ifade edilebilecek kolektif bellek önemli bir paya sahiptir. Mills'e (2014: 46) göre, insanların kendilerinin belirli bir kimliği paylaştıklarını tahayyül etme süreçlerindeki en önemli unsurlardan biri, geçmişe dair ortak bir hafızanın yeniden üretimidir. Yeni bir mekâna yerleşen göçmenler, bir taraftan yeni mekâna alışmaya ve bu mekânda kendisine alan açmaya ve yer tutmaya çalışırken diğer taraftan hayatta kalma, yok olmama, sahip olduklarını (maddimanevi) kaybetmeme çabası içerisine girmektedir (Ekici ve Tuncer, 2015: 15). Böylece göç sonrası yeni yerleşilen bölgelerde mekânın kimlik üzerinden düzenlenmesi kolektif belleğin yeniden üretimini sağladığ1 gibi o mekâna olan aidiyeti de güçlendirir.

"Bellek, kesintiye uğradığımız noktadan yeniden başlamamız gerektiğini ve bir süre için, aslında hiçbir şeyin değişmediğini düşünmemizi sağlar. Bu sayede bellek, süreklilik ipini yeniden dügümleyerek kolektif hafızanın bir an bile kesintiye uğradığı hissine kapılmadan, bir aşamadan diğerine geçmemize yardım eder (Halbwach, 2017: 80)”. Kolektif hafıza ile mekânın şekillendirilmesi Halbwach'ın 
bahsettiği “düğüm"ün oluşmasındaki en büyük etkendir. Nora'nın (2006: 17) da vurguladığı üzere süreklilik duygusunun kökü mekândadır. Çünkü mekân belleğe yakından bağlıdır; belleğin soyut doğasının insanlık deneyiminin ontolojik yapısıyla somutlaşmasını sağlamaktadır (Tilley, 1994 akt. Bader, 2018: 4). Bir mekân; hafızanın edimsel yönünü oluşturur, bir uygulama ve sürekli inşa alanı yaratır ve bu özelliği ile bireylerin, geçmişi şimdiki zamanda deneyimlemelerini ve inşa etmelerini sağlar. Kolektif bellek, kimlik inşa sürecinin vazgeçilmez bir aracı olarak, sadece geçmişi yansıtmaz, aynı zamanda insanların dünyayı anlamlandırmasına aracılık eden sembolik çerçeveler ve anlamlar sağlayarak bugünün gerçekliğini şekillendirmek suretiyle anlam yapıcı bir rol üstlenir. Bu rol sayesinde topluluk üyelerinde aynı kaderi paylaşma duygusu uyandırır (Bilgin, 2013). Göçmenler tarafından mekânda yapılan düzenlemelerin de genelde büyük yapısal değişikliklerin yanı sıra semboller ve isimlendirmeler ile sunulduğu görülmektedir. Bunun yanı sıra, göçmenlerin menşe toplumda yer alan mekân anlatılarına artık ev sahibi ülkede ritüellerin sürdürüldüğü mekânlar eşlik eder. Bu şekilde hafiza ikili bir aidiyet duygusu ile şekillenir. Bu mekânlar zamanla göçmenler tarafından kimliğin sembolleri ile donatılarak bir aidiyet alanına dönüşür. Bu mekânlarda, gündelik yaşam pratikleri her iki toplumun kültürü ile yapılanır. Göçmenler yerleştiği bölgelerde topluluklar oluşturarak, kendi dillerini sürdürür, yerel toplumun dilini öğrenir ve her iki toplumda yaşanılan olaylara ilgi duyarlar. Bu hafıza tarafından şekillenen mekânlar kimliğin ve aidiyetin birlikte sunulduğu yerlere dönüşür.

\section{Araştırma Alanı ve Yöntem}

Niteliksel araştırma, sosyal olanın bilgisinin insanların kendi ifade ve anlatılarından derlendiği bir araştırma özelliği gösterir (Kümbetoğlu, 2019: 38). Bu nedenle çalışmada nitel araştırma yöntemi kullanılarak, göç-hafıza-mekân arasındaki ilişkiler bireylerin anlatılarından yola çıkılarak anlaşılmaya çalışılmıştır. Bu amaçla, 2018 yılı Ocak, Şubat, Nisan ve Eylül aylarında İstanbul ili, Bayrampaşa ilçesi, Yıldırım Mahallesi'nde (Şekil 1) saha araştırması yapılmıştır. Bayrampaşa ilçesi ve özellikle Yıldırım Mahallesi Yugoslavya ${ }^{1}$ ve Türkiye'nin birçok farklı bölgesinden göç alarak oluşmuş/gelişmiştir. Bu nedenle araştırma alanının seçiminde Bayrampaşa ilçesi ve Yıldırım Mahallesi'ne gelen Boşnakların kolektif bellekleri üzerinden mekânı şekillendirmelerinin görünürlüğü etkili olmuştur.

İlçenin tarihi gelişimini betimlemek gerekirse; İlçenin temelleri, 1927 yılında Filibe'den gelen birkaç göçmen ile atılmıştır. 1950'lerde Makedonya'dan, 1960'lı yıllarda beldenin \%30-35'ini teşkil eden Trakya, Karadeniz, Orta Anadolu halkının yanı sıra, Yugoslavya'dan göç eden Boşnaklarla doruğa ulaşan göç dalgası Bayrampaşa'nın sosyo-kültürel altyapısının oluşmasında etkili olmuştur². 1960 yılında ikinci kez önemli bir nüfus artışı olmuştur. Bu durumun yaşanmasında ilçenin, 955/92/846 sayılı 11.3.1955 tarihli İstanbul Belediye Meclisi kararı ile sanayi bölgesi olarak ilan edilmesinin payı büyüktür. Bu tarihte, 4-5 tane olan fabrika sayıs1 1966 yılına kadar 40'1 bulmuştur (Bayakır, 1998: 39). Bu süreçte, 1960 'ta 4.000 hane iken, 1965 'te 10.000 haneye, 1970 'te ise 40.000 haneye kadar artmıştır. Paralel şekilde, 1965 'te 69.064 olan nüfus 1970 yılında \%79'luk bir artışla 124.083'e yükselmiştir (Bayakır, 1998: 11). Günümüzde Bayrampaşa ilçesinin nüfusu 269.950, Yıldırım Mahallesinin ise 52.884' dir (TÜİK, 2020). İlçenin en kalabalık mahallesidir.

Mekânda yaşanılan göçler nedeniyle var olan yerleşim alanları genişlemiş, yeni yerleşim alanları oluşturulmuştur. Böylece, Yıldırım Mahallesi göç ile birlikte gelişen mekânlardan biri olmuştur 
(Bayakır, 1998; Tekinkaya, 2015). İlçenin sanayileşmesi ve mahalleye göçlerin yaşanması yeni mahallerin kurulmasını, var olanların sınırlarını genişleterek yeni yerleşim alanlarının oluşmasını sağlamıştır. Günümüzde, mahallede hem Türkiye'nin hem de Balkanların birçok bölgesinden göç eden bireyler bulunmaktadır. Özellikle, Bayrampaşa ilçesinde ve Yıldırım Mahallesinde Boşnakların yanı sıra Arnavutluk, Bulgaristan ve Makedonya'dan gelen birçok göçmen yaşamaktadır. İlçede bulunan mahalleler arasında Yıldırım Mahallesinin nüfusu diğer mahallere oranla daha yüksektir. Yıldırım Mahallesi’nin bu heterojen nüfus yapısına karşın mahallenin Boşnaklarla anılması ve Boşnak nüfusunun daha yoğun olması çalışma alanı olarak seçilmesinde etkili olmuştur. Yine ilçede, farklı mahalleler farklı grup göçmenlerle anılmaktadir.

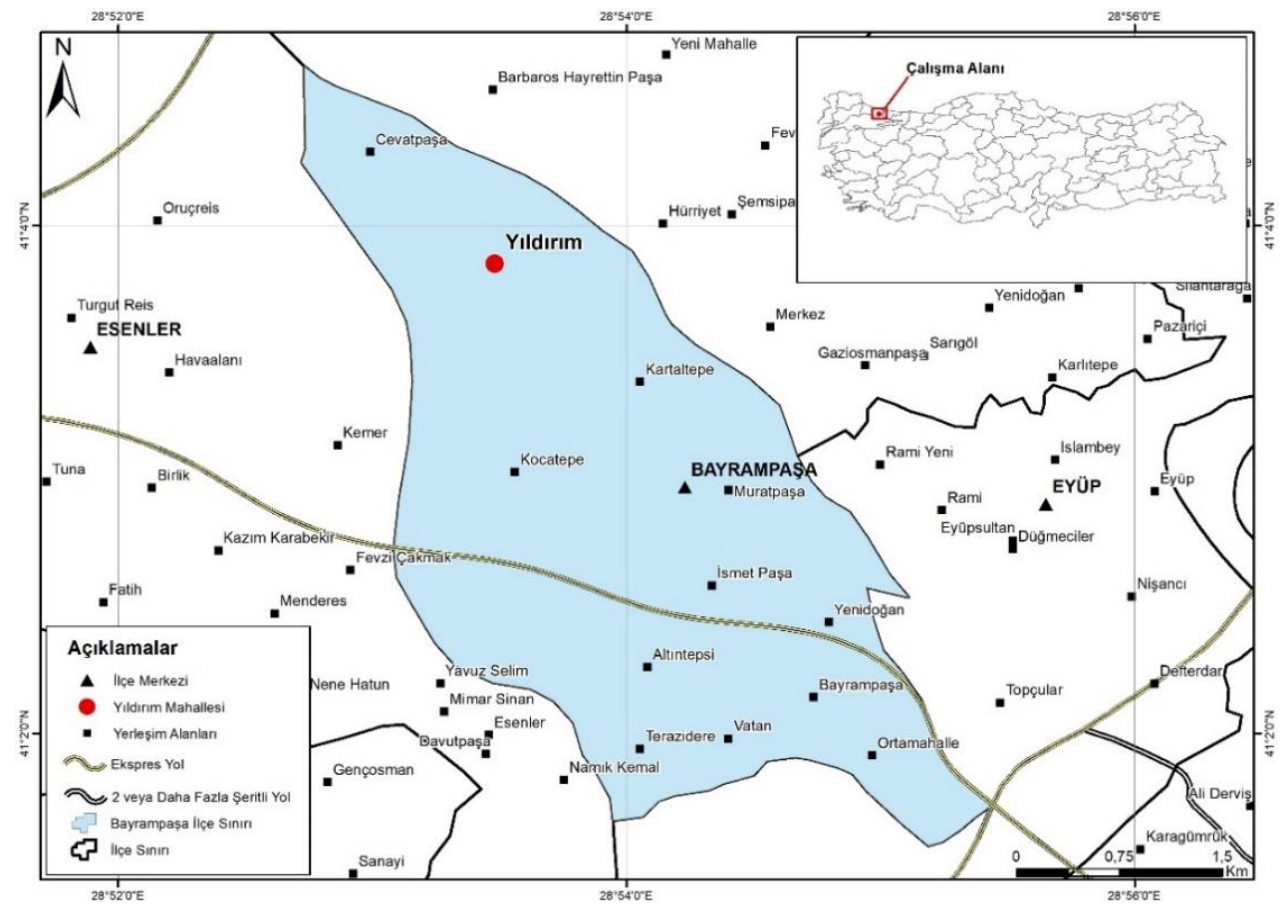

Şekil 1. Yıldırım mahallesinin lokasyon haritas ${ }^{3}$.

Mahallenin farklı etnik topluluğa ait bireyleri bünyesinde barındırması katılımcılara erişim sürecini etkilemiştir. Aynı zamanda araştırma konusu da değişmiş̧tir. Araştırma soruları sahada oluşmuştur. İlk olarak sahaya çıkıldı̆̆ında araştırma konusu Yugoslavya'dan Türkiye'ye yaşanılan göçlerin sosyo-mekânsal etkileri olarak tasarlanmıştır. Bu süreçte, zamanla sahada vakit geçirdikçe ve mahallenin yapısı, anlatılar ve gözlemler araştırma konusunun ve var olan soruların değişmesine neden olmuştur. Bir açıdan, katılımcılar hem soruları oluşturarak hem de soruları yanıtlayarak çalışmaya katkı sağlamıştır. İlk olarak, göç sürecini deneyimleyen birinci nesil göçmenlere ${ }^{4}$ bir diğer ifade ile iletişimsel belleğin ${ }^{5}$ üyeleri ile görüşmek için her kapı çalınmıştır. Bu noktada, katılımcıların yabancıları konutlarına almamaları, katılımcılara erişim konusunda yaşanılan en büyük sorun olmuştur. Bu durum, çalışmada erkeklere oranla daha az kadının yer almasına neden olmuştur. Apartmanlarda, yarı açık kapılar arasında görüşmeler yapılmıştır. Bu durum, araştırma sürecini olumsuz etkilemiştir. Bu nedenle farklı alanlarda düzenlenen faaliyetlere katılarak farklı bireyler ile görüşülmeye çalışılmıştır. İlk olarak, Türkiye Bosna Sancak Kültür ve Yardımlaşma Derneği’nin (TBSKYD) düzenlediği sosyal etkinliklere ka- 
tılım sağlanmıştır. Örneğin; TBSKYD Kadın Kolları tarafından, Türkiye'nin Suriye'ye karşı düzenlediği Zeytindalı Operasyonu'nda yer alan ve Doğu ve Güneydoğu' da görev yapan askerlere, şapka, eldiven, çorap ve unlu mamüller göndermek için etkinlik düzenlenmiştir. İki tane bere örerek, derneğe gidilmiştir. Bu sırada, dernekte birçok kişi ile görüşülmüss, bu kişiler birinci nesil göçmenler ile iletişim kurulmasında aracı olmuşlardır. Bu şekilde birçok katılımcıya erişilmiştir. Bazı katılımcılar görüşmeye başlamadan önce birtakım sorular yöneltmiştir. Genelde katılımcılar, onların göç tarihi hakkında araştırmacının bilgisini ölçen ve son dönemlerde Boşnaklarla ilgili gündemde olan konular hakkındaki birkaç soru yöneltmişlerdir ${ }^{6}$. Bu sorular yanıtlanarak görüşmeye başlanmıştır.

Tüm bu sürecin sonunda araştırma sahasında, kartopu örneklem kullanılarak birinci nesil göçmenler bir diğer ifade ile iletişimsel belleğin üyelerinden oluşan 20 katılımcı ile görüşme yapılmıştır. Örneklem grubu belirlendikten sonra, Türkçe yarı yapılandırılmış görüşme formu ${ }^{7}$ kullanılarak, 4 Kadın ve 3 erkek ile derinlemesine ve 6 ve 7 kişiden oluşan iki erkek grup ile odak grup görüşmesi yapılmıştır. Derinlemesine görüşme yapılan grubun yaş aralığı $63-84$, odak grup görüşmesi yapılan iki grubun yaş aralığ 1 58-76'dır. Odak grup görüşmeleri kahvehanelerde yapılmıştır. Bunun temel nedeni araştırma sahası içinde kamusal mekânda kadınların görünürlüğünün az olmasıdır. Diğer görüşmeler, katılımcıların iş yerlerinde, yaşadıkları konutlarda ve dernekte yapılmıştır. Türkçe bilmeyen katılımcılar ile yapılan görüşmeler esnasında aileden Türkçe bilen kişilerin yardımı alınmıştır. Yarı yapılandırılmış görüşmelerin yanı sıra, yapılandırılmamış görüşmeler de yapılmıştır. Bu görüşmeler sırasında not alınmamış, sorular sohbetin akışına göre şekillenmiştir. Bu görüşmeleri eksik bir şekilde aktarma ihtimali göz önünde bulundurularak çalışmada bu görüşmelere yer verilmemiştir. Görüşmelerin yanı sıra sahada gözlem yapılarak dernek, işletmeler, kafeler ve marketler ziyaret edilmiştir. Boşnak kimliği kullanılarak açılan işletmelerde bulunan ürünler ve restoranların menüleri incelenmiştir. Aynı zamanda, mekânların içerisinde ve dışarısında kullanılan Boşnak kimliğine ait semboller incelenmiş, fotoğraflar çekilmiştir. Boşnak Dünyası Gazetesi, Yıldırım Bosna Spor Kulübü Dergisi ve TBSKYD’nin Bosna Sancak Kültür ve Yardımlaşma adıyla dönemsel olarak yayınladığı dergi incelenmiştir Ayrıca, Yıldırım Mahallesi'nde kültürel bellek aktarımında Boşnak Müziği ve halk oyunlarının etkili olduğunun anlaşılması üzerine göçmenlerin kına gecelerine ve dügünlerine katılım sağlanarak, kültürel pratikler ve ritüellerin sürdürülme biçimi de gözlemlenmiştir. Elde edilen bulgular betimsel analiz yöntemi kullanılarak analiz edilmiştir.

\section{Bulgular}

\subsection{Yıldırım Mahallesinin Ulusötesi Bir Mekâna Dönüşme Süreci}

Ulusötesi göçmenlerin hareket edebilmesinde menşe toplumun ve ev sahibi toplumun yöneticilerinin siyasi tavrı önemlidir. Ülkelerin ortaya koymuş olduğu politikalar; hareketliliği arttırabilir ya da azaltabilir, göçmenlerin harekete katılım biçimini ve kurulan ağların yapısını değiştirebilir. Boşnakların göç etmelerinde ve ulusötesi ilişkilerin kurulmasında Türkiye ve Yugoslavya'nın politikaları önem arz etmektedir. Türkiye ve Yugoslavya arasında 1953 Anlaşması $^{8}$ olarak bilinen Centilmenlik Anlaşması Boşnakların Türkiye'ye göç etmesinde etkili olmuştur (Ağanoğlu, 2013; Celep, 2019; Çalışkan, 2019; Çavuşoğlu, 2007, 2014; Erken, 2018; Özgür Baklacıŏlu, 2010; Zorbay, 2017). Bu süreçte anlaşmayla 
birlikte; Yugoslavya'dan, 1950-1958 yılları arasında 104.372 (Zaim, 1957: 446), 1946-1960 yılları arasinda 152.000, 1961-1970 yılları arasında ise 30.502 kişi olmak üzere 1946-1970 yılları arasında toplam 182.505 kişi gelmiştir ${ }^{9}$ (Kirişçi, 1995: 70). Geray (2019: 21-22), 1923-1960 yılları arasında 269.101 kişinin geldiğini bu sayının bütün toplam göçmen nüfusun \%22,4 üne karşılık geldiğini, bu yıllar arasında gelenlerin \%56,4 'ünü teşkil eden 151.812 göçmenin 1953-1960 yılları içinde geldiğini belirtir. Kirişçi (1995: 69), Bulgaristan'dan sonra Türkiye'ye en büyük göç hareketinin Yugoslavya'dan yapıldığının altını çizmektedir.

Anlaşma, Boşnaklar için sınırların aşımını kolaylaştırırken bir sonraki neslin yer değiştirme pratiklerine katılması için hareket mekanizmasını oluşturmuştur. Bu doğrultuda serbest göçmen olarak gelen Boşnakların geneli Türkiye'nin farklı bölgelerine göç etmişlerdir. Göç süreci ile ilgili bazı kaynaklarda Demokrat Parti'nin (DP), ilk dönem gelen göçmenlerin bir kısmını belirlediği alanlara yerleştirdiği belirtilmişsirir ${ }^{10}$. Katılımcıların bir kısmı DP'nin onları belirlediği alanlara yerleştirdiğini, bir kısmı ise, kendi istekleriyle yerleştiklerini ifade etmiştir. Ayrıca, Türkiye'nin ve İstanbul'un farklı bölgelerinde yaşayan bireyler de mahalleye göç etmiştir ${ }^{11}$. Gaziosmanpaşa, Eyüp ve Bayrampaşa ilçelerine bağl1; Taşlıtarla, Küçükköy, Rami ve Yıldırım Mahallesi bu alanlardan birkaçını oluşturmaktadır ${ }^{12}$. Göç akışının sürmesiyle birlikte yerleşim alanlarının sınırları genişletilerek yeni yerleşim alanları oluşturulmuştur. Yıldırım Mahallesi, Yugoslavya ve Türkiye'nin farklı bölgelerinden gelen göçmenlerle birlikte sınırlarını genişletmiştir. Bu süreçte göçmenler arasında evliliklerin yaşanması aile yapılarının gelişmesini sağlarken mekânsal üretimin hızlanmasında da etkili olmuştur. Demografinin yanı sıra sosyal ve kültürel sermayeleriyle birlikte ekonomik sermayelerinin gelişmesi iki ulus devlet arasinda hareket etmelerini kolaylaştırmıştır. Bu süreçte Yugoslavya ve Türkiye'nin politik tavrı, hareketliliğin yaşanmasında etkili olmuştur. Sosyalist komşularının aksine, Yugoslavya'nın Bağlantısızlar Hareketi'nin çekirdek üyesi olması, sınırlarını Doğu ve batıya karşı çoğu zaman geçirgenleştirmiş; bu özel durum sayesinde Soğuk Savaş boyunca Yugoslavya ve Türkiye arasındaki insan hareketliliği kolaylaşmıştır (Schad, 2015: 6). Bu durum, Yıldırım Mahallesi'nin iki ulus devlet arasında ulusaşırı sosyal bir mekâna dönüşmesine katkı sağlamıştır. Bu süreç, Boşnakların mahalleye yerleşmeleri ile başlamış, ekonomik sermayelerinin gelişmesi ile devam etmiştir.

Yıldırım Mahallesi'ne yerleşen Boşnaklar; Bayrampaşa, Aksaray, Unkapanı ve Topkapı gibi üretim ve tüketimin yoğun olduğu ve emek açığının bulunduğu alanlarda çalışmaya başlamıştır. Ayrıca, ip ve şişe fabrikası olmak üzere hâl, inşaat, tekstil gibi birçok alanda emek piyasasına dâhil olmuşlardır. Katılımc1ların sözleri ile:

“Geldik Türkiye’ye hiçbir şeyimiz yok. İ̧̧ aramaya başladık. Türkçe bilmiyoruz. Anlamıyoruz, anlatılsa da. İste burada fabrika çoktu. Girdim şişe fabrikasına, düşük ücretlerle, uzun süre çalışırdık (Erkek, 84)."

"Bizim geldiğimizde bu bölgede fabrikalar kurulmuştu. Türkiye, bu dönemde sanayileşmenin etkisiyle elemana ihtiyaç duyuyordu. Bizim için bu durum, büyük bir şanstı (Kadın, 78)."

Yerel piyasaya eklemlenenlerin yanı sıra yurt dışına misafir işçi olarak gidenler de olmuştur. Yerel piyasadan elde edilen sermayenin yanı sıra yurtdışında çalışan göçmenlerin gönderdiği dövizler/ 
para havaleleri bazı ailelerin mahallede mülk edinmesine katkı sağlamıştır. Aynı zamanda Boşnakların ekonomik sermayesinin gelişmesi ve bazı göçmenler tarafından gönderilen dövizler Boşnakların eğitim harcamaları ve yerel piyasaya eklemlenmeleri için kullanılmıştır. Katılımcıların sözleriyle:

“Almanya'dan emekliyim. Emekli olunca tekrar, buraya döndüm... çalıştık, biriktirdik, çocuklarımızı okuttuk, eğitime çok değer verdik, hala da veriyoruz. Bizler birçok kurumda çalışıyoruz. Aramızdan her alanda biri var. Avukat, doktor, milletvekili, sporcu, öğretmen ...devletin farklı kademelerinde yer aldık (Erkek, 81)."

“Almanya ve Irak'ta çalı̧̧maya gittim. Saddam'ın inşaatı o dönem popülerdi, inşaat işinde çalıştım, sonra Yıldırım Mahallesi'ne geri döndüm. Yugoslavya'da duvar ustasıydım, zaten inşaat işinden anlıyordum, bu da farklı yerlerde kolay iş bulmamı sağladı (Erkek, 84).”

“Yugoslavya'dan Amerika'ya, İsviçre birçok bölgeye göç oldu. Biz Türkiye’ye geldikten sonra, buradan Almanya 'ya ve Irak'a giderek çalıştılar. Biz ise burada kaldık, çeşitli alanlarda çalıştım. Özellikle fabrikalarda ailecek çalıştık (Odak Grup 1).”

“Birçok ülkede çalıştım, Almanya'da yaşadım bir süre, daha sonra Irak, Libya'da çalıştım. Daha sonra geri döndüm buraya. Oğlumu Kıbrıs'ta okuttum (Erkek, 77)."

Ekonomik sermayeleri, beşerî sermayelerinin gelişmesini sağlayarak Boşnakların yerel toplum içerisindeki görünürlüğünü arttırmıştır. Ayrıca, Boşnakların mülk edinmesini kolaylaştıran unsurlardan biri de arsaların büyük bir kısmını elinde bulunduran Ermeni bir aile olmuştur. Bir katılımcı ile yapılan görüşme bu durumu daha anlaş1ır kılmaktadır:

"5 kuruş paramız yoktu. Akrabalarımızın yanına yerleştik. Ertesi gün tanıdıklar aracıllğıyla işe başladık. Ben ve 4 erkek kardeşim okuldan sonra çalışırdık. Simit satardık, hamallık yapardık, halde çalışırdık. Anne ve babalarımı iplik fabrikasında çalışıyorlardı. Bu bölgede yaşayan bir Ermeni: 'burası sizin olsun her ay bana ödemesini yaparsınız' diyerek bize elindeki arsaları sattı. Senet imzalamadık deftere yazardı. Biz Boşnaklar borçlarına sadık insanlarızdır, borçlarımızı ödedik. Aldığımız her yeri önce aile apartmanı yaptık. Ailecek bir binada yaşıyorduk. Gecekondu tarzı yapılar oluşturmadık. Yani kaçak tarzda yapılar oluşturmadik. Tabi o şekilde ev yapanlar da olmuştur (Erkek, 68).”

“Suriçi'nin dışında kalan alanlar daha ucuzdu. Sultan Ahmet, Laleli tarafları pahalıydt. Buralar daha ucuzdu. Bizler burada uzunca yaşayacağımız düşündüğ̈̈müz için ev sahibi olmak bizim için önemliydi. Kendimizi güvende hissetmek istedik. Ev almak, burada çok etkili oldu. Birlikte bir yaşam alanı oluşturduk. Birbirimize yardım ettik. Bizim için Boşnaklar zengindir derler. Biz hep birbirimize destek olduk. Bende varsa ona verdim, Onda varsa o da bana verdi, hep yardım ettik. Bu şekilde birbirimizi hep tanıdık, zamanla kız alıp vermeler oldu. Yeni akrabalık ilişkilerinin gelişmesini sağladı. Kendimizi daha güvende hissettik (Kadın, 63)." 


\subsection{Sosyo-Kültürel Pratikler Yoluyla Kolektif Belleğin Yeniden İnşas1}

Mahalleye yerleşen Boşnaklar, çeşitli iş alanlarında çalışarak sermaye birikiminde bulunmuşlardır. Alınan arsalarda geniş ailelerin yaşayacağı şekilde çok katlı konutlar yapılmıştır. Boşnakların bir arada yaşaması, gündelik hayat içerisinde yardımlaşmalarını ve dayanışmalarını güçlendirerek kültürün sürdürülmesinde etkili olmuştur. Göçmenlerin, kültürel sermayeleri (kendi durumlarına ve bununla nasıl baş edeceklerine ilişkin kolektif bilgi) ve sosyal sermayeleri (göç ve cemaat oluşum sürecini düzenleyen ağlar) (Castles ve Miller, 2008: 33), yeni yerlere yerleşmelerinde ve daha sonraki süreçlerde yaşamlarını kolaylaştırmıştır. Boşnakların, ekonomik sermayelerinin yanı sıra sosyal sermayeleri, Yıldırım Mahallesi'ne yerleşmelerinde yardımcı olmuştur. Bunun yanı sıra, farklı bölgelerde yaşayan Boşnakların birçoğu, Yıldırım Mahallesi'ne Boşnakça konuşulduğunu duydukları için yerleşmeye karar verdiklerini belirtmiştir. Bu durum Boşnakların bir araya gelerek yardımlaşmalarını, sorunlar karşısında ortak çözüm yolları bulmalarını, güven ve aidiyet duygularıyla yeni yaşamlarına tutunmalarına aracılık etmiştir. Bununla birlikte, farklı şehirlere veya aynı şehirde farklı ilçelere yerleştirilen Boşnaklar, yaşadıkları yerlerden dil problemi ve toplumsal dışlanma sorunları nedeniyle taşınmak zorunda kalmışlardır. Katılımcıların birçoğu Yıldırım Mahallesi’nde Boşnakların yaşadıklarını ve Boşnakça konuştuklarını duydukları için bu alanı tercih ettiklerini ifade etmişlerdir. Bu durum dilin paratoner gibi Boşnakları Yıldırım Mahallesi'ne çektiğini göstermektedir. Görüşmeden bir kesit:

“ilk olarak Karagümrük'ten ev almayı düşünüyorduk. O zamanlar Yıldırım Mahallesi’nde az ev vardı. Yıldırım Mahallesi'nin aşağısında akrabalarımız vardı. Onların yanına geldik. Baktık herkes Boşnakça konuşuyor, kalmaya karar verdik. Buradan, Yıldırım Mahallesi'nden arsa almak kısmetmiş. Başka yere gitsem Boşnakça konuşamayacaktım. Bu sayede dilimi unutmadım (Erkek, 84)."

Kulaktan kulağa duyumlar eşliğinde mahallenin keşfi, birçok Boşnak'ın mahalleye göç etmesini sağlamıştır. Bu göç hareketi, belleklerin birbirine temas etmesini ve eklenmesini sağlayarak iletişimsel belleğin paydaşlarını bir araya getirmiş, kimliğin yeniden üretilmesini sağlayarak aidiyetlik bağlarını güçlendirmiştir. Göç sonrası yaşanılan sorunlar karşısında Yıldırım Mahallesi, hafızasını yaşatmak isteyen Boşnakların sığınağı olmuştur. Boşnakçanın, Yıldırım Mahallesi'ne Boşnakları çekmesi ise yadsınamaz bir gerçektir. "Heidegger, dili varlı̆̆ın evi olarak görür. Ve her dilin bir topluma ait olduğunu, kendi toplumunun sinırlarını çizdiğini, kendi içinde dile mahsus olan bir cemaat oluşturduklarını Gadamar ise insan cemaatlerinin dil cemaatleri olduğunu, dilin ortak bir anlamın paylaşılması olduğunu söyler" (Yıldırım, 2017: 79). Birey, ait olmuş olduğu dilin anlam dünyasına uygun kendine bir dünya üretir. Yaşamını bu dünyanın ona sunduğu dil sayesinde anlamlandırır. Boşnaklar da dilin sunduğu aynı anlam dünyası ekseninde birleşmişlerdir. Çünkü dil her topluma özgü anlamlar üretir ve onlara güven sunar. Ortak dil, grup içinde dışarıya karşı güvenlik duygusu oluşturmuştur. Bu şekilde göçmenler, menşe bölgeyi yaşatacak gruplar oluşturarak, geride kalan topluma bağlılıklarını ve aidiyet duygularını perçinleyerek ev sahibi toplumun yerel ortamına eklemlenmişlerdir. Boşnaklar, bu şekilde gündelik yaşamlarında bir arada kalarak alan onların kimliklerini sürdürdükleri ve ritüellerini devam ettirdikleri bir kimlik ve aidiyetlik mekânına dönüştürmüşlerdir. Bu alanda Boşnaklar anma etkinlikleri, göç ve kimlikleri hakkında seminerler, eğlence ve kültür günleri düzenlerler. Günlük yaşamlarında hem Boş- 
nakça hem de Türkçe konuşurlar, iki ülkenin haberlerini okurlar, müziklerini dinlerler ve yemek kültürlerini sürdürürler. Özel günlerinde Boşnak şalvarlarını giyerler. Bunlar artık Boşnakların gündelik yaşamlarının bir bileşeni haline gelmiştir ve Boşnakların gündelik yaşamı iki toplumun kültürü ile şekillenmektedir. Bu birliktelik kolektif hafıza ile üretilen mekânlarda iç içe geçerek yaşamlarını anlamlandırmakta aidiyetlik ve kimlik duygularını güçlendirmektedir.

Bireysel ve kolektif sosyo-kültürel pratikler Türkiye Bosna Sancak Dayanışma ve Kültür Derneği'nin 1989 yılında kurulması ile birlikte politik bir nitelik de kazanmıştır. Yerel toplum ve menşe bölgede temsilciler ve milletvekilleri derneği ziyaret etmektedir. Yerel toplumda Boşnaklar ile ilgili siyasal veya toplumsal birçok konu hakkında kamuoyu açıklamaları yapmaktadırlar. Aynı şekilde, menşe ve ev sahibi toplumda alınan siyasal kararlar ile ilgili kamuoyu açıklamaları yaparak, iki toplumun siyasi hayatında Boşnak toplumunu temsil etmektedir. Kamuoyu açıklamalarının yanı sıra, sosyal yardımlar aracılığıyla köken bölgeye maddi yardımlar yapmaktadırlar. Yakın bir tarihte Sancak Bölgesinin Novi Pazar başta olmak üzere bazı şehirlerinde Covid-19 vakalarının artması nedeniyle bir tır dolusu tıbbi malzeme desteği sağlanmıştır. Bu faaliyetler sadece menşe bölge için değil, Türkiye için de yapılmıştır. Özellikle Covid-19 pandemi sürecinde, İstanbul'da bulunan hastanelerde görev yapan sağlık çalışanlarına, emniyet ve itfaiye gibi birçok kamu kurumunda çalışanlara 1 ton Boşnak Böreği gönderilmiştir. Politik faaliyetleri kamuoyu açıklamaları ve yardım faaliyetlerinde bulunmalarının yanı sıra anma etkinlikleri, kültür günleri ve geziler düzenlemektedirler. Dönemlik olarak Yıldırım Bosna Spor Kulübü ve Bosna Sancak Derneği yayın yapmaktadır. Ayrıca, her ay Bosnak Dünyası adlı bir gazete çıkartılmaktadır. Türkiye, Balkanlar ile ilgili özelde Bosna, Sancak Bölgesi ve Yıldırım Mahallesi ile ilgili haberler yer almaktadır. Ayrıca Gazetede, Boşnakların işletmelerinin tanıtımı da yapılarak ekonomik açıdan destek de sağlanmaktadır. Katılımcının sözleri ile:

“Elimizden geldiği kadar Sancak'a yardım gönderiyoruz. Oraya yaptırırken buraya da yapıyoruz. Aynı coğrafyalarda yaşamıyoruz ama hala bağllyız. Artık buradayız. Zaten buradan göç ettik ve yine buraya geldik ama orada akrabalarımız var. Sonuçta oradan geldik, baksanıza küçük Sancak burası (Odak Grup 2)."

Yerel toplum ve menşe bölge ile politik ilişkiler sürdürülürken Boşnakların, ekonomik sermayeleri gelişmesiyle birlikte Yıldırım Mahallesi, Bosna ve Sancak arasında hareketlilik artmıştır. Bu hareketlilik, mahallede seyahat acentelerinin açılmasıyla birlikte ivme kazanmıştır. Bu sayede, köken bölgeye günlük seyahatler düzenlenmeye başlamıştır. Yıldırım Mahallesi’nde yaşayan Boşnaklar tarafından başlasa da zamanla karşı1lıklı bir ilişki gelişmiş, Bosna ve Sancak bölgesinde yaşayan bireyler Yıldırım Mahallesi'ni ziyaret etmeye başlamıştır. Acenteler, farklı mekânlarda yaşayan yerleşik bireyler için hareketli bir yaşamı başlatarak yön vermiştir. Bununla birlikte bu hareketlilik; birinci nesil Boşnaklar için aidiyetliğin sürdürülmesini sağlarken, ikinci ve üçüncü nesilde aidiyetlik ilişkilerini oluşturmaktadır. Katılımcının sözleri ile:

“Bizler Sancak ve Bosna'ya her yıl gideriz. Çocuklarımız yılda birkaç sefer gider. Kendi öz topraklarımızı unutmak istemiyoruz. Akrabalarımı hala orada onları ziyarete gidiyoruz. Ve burada yaşıyoruz. Hepimiz Sancakluyız, birbirimizi tanırız, severiz destek oluruz. 
Kültür ve geleneklerimizi yaşatırız. Çocuklarımıza unutturmamaya çalışıoruz (Erkek, 77)."

Seyahatler ziyaret etmeyi kolaylaştırdığı gibi kültürel ürünlerin Yıldırım Mahallesi’ne taşınmasında etkili olmuştur. Bosna ya da Sancak Bölgesinde yaşayanlar Yıldırım Mahallesi’ndeki akrabalarına kendi kültürel ürünleri göndermektedir. Bazı restoranlar, yöresel yemeklerin yapımında kullanılan malzemeleri yine menşe bölgeden getirerek mahallede işletmelerinde sunmaktadırlar. Katılıcının sözleri ile:

"Boşnak yemekleri satan bazı kişiler bazı ürünleri getirmektedir. Kendi işletmelerinde satıyorlar. Orada bize has lezzetler vardır. Onlarl gelirken getiririz ya da bize otobüsle gönderirler (Kadın, 72)."

4.3. Ötekilik İçerisinde Benlik Çatlaması: Kimlik

Geçmişi denetim altında tutan, geleceği de denetim altında tutar.

Geçmişin gerçekten var olduğu kanısında misın, Winston?

Orwell, 2019: 268

Kimlik, hareketliliğe bağlı sosyal süreçler içerisinde oluşup aynı zamanda birden fazla toplumla diyalektik ilişki içerisindedir (Yazgan, 2016: 288). Gruplar ve bireyler kimliklerini ötekinden referans alarak inşa sürecine girerler. Özellikle hareketli bireyler gidilen yeni bölgelerde yeni kimlikler ve kültürler ile karşılaşır. Bu karşılaşmalar sonucunda, göçmen veya azınlık kültürlerinin ihtiyaçları, deneyimleri ve güncel toplumsal çevreyle etkileşimleri ekseninde sürekli yeniden yaratılır. Bu nedenle, bir etnik azınlık hem ötekinin tanımı hem de kendi tanımının bir ürünü olarak kendi kimliğini inşa eder (Castles ve Miller, 2008: 45). Boşnaklar hedef bölgede yerleştikleri alanda homojen bir topluluk oluşturmuşlardır. Zamanla iktidarın Bayrampaşa ilçesini sanayi alanı olarak belirlemesi, farklı kimliklerin mekânda görülmesini sağlamış, mahalle ötekiliklerin eşiği haline gelmiştir. Stavrides (2016) eşiklerin, toplumsal kimliklerin dönüşüm süreçlerine işaret ettiğini söyler. Eşiklerde gezinen heterojen kimlikler Boşnak homojen kimliğinin üretiminde etkili olmuştur. Farklı kimliklerin aynı mekânda yaşaması Boşnaklar açısından beklenilmedik durumların yaşanmasına neden olmuştur. Bu karşılaşmalar sonucunda gâvur olarak adlandırılan Boşnaklar mahallede ötekileştirilen grup olmuştur. Her ötekilik ve gâvur damgasına karşı Boşnaklar dışarıya karşı kendilerini iyice kapatmış, aralarına farklı kimlikten bireyleri almamışlardır. Görüşmeden bir kesit sunmak gerekirse:

"Mahalleye ilk geldiğimizde Boşnakça konuşuyorduk, Türkçe bilen çok azdl. Söylenilenleri anlamıyorduk ama yapılanları anlıyorduk. İstenmediğimizi biliyorduk. Düşük maaşla çalıştık, ne söyleseler yaptık. Fazla çalışırdık parasını alamazdık. Ama kazandıkça birbirimize yardım ederek evler aldık. Dışarıdan gelenleri içimize almadık, bu mahallede kim oturur biliriz, nerde çalışır, neye ihtiyacı olur hepsini biliriz (Odak Grup 1).”

"Hiç unutmuyorum, babamın bir ayağı yoktu. Pazara gitmiştik tabi ben küçügüum tam anlamıyorum. Bir kilo meyve istedik. Bize bakıp gülerek çürük meyveleri verdi. Babama, bize çürük demek istedi. Çünkü babamın bir ayağı yoktu. Askerdeyken kaybetmişsi. Babam bana belli etmese de çok zoruna gitmişti. Sonra bize komünistler, siz gâvursunuz diye arkamızdan bağırmışlardı (Erkek, 84).” 
Katılımcı, çevredeki baskının daha net bir şekilde yansıtıldığını ve kendilerine karşı küçük düşürücü davranışlarda bulunulduğunu ifade etmiştir. Yıllar geçse de hala hafizasında bu durumun yer alması günümüzde mahallede bulunan soyut duvarların somut kaynağını sunmaktadır. Castles (2002), göçmenlerin marjinalleşmeyi ve ırkçıllğı tecrübe ettiği yerlerde, toplumsal dayanışma bağlarını ve ulusötesi bağlantılarını harekete geçirdiklerini belirtir. Bazı katılımcılar, 30-40 yıl önceye kadar dışarıdan öteki olarak gördükleri bireyleri mahalleye almadıklarını belirtmişlerdir. Her ne kadar günümüzde bu durum söz konusu olmasa da tamamen kaybolduğunu söylemek pek mümkün değildir. Genç kuşaklar için bugün hala geçerliliğini koruyan duvarların kaynağını iletişimsel belleğin paydaşları, ev sahibi toplumun dışlama pratiklerinden oluşan anılarıyla açıklamaktadırlar. Bu anılar geçmişin seçilmiş ve yorumlanmış hikâyeleridir, Boşnakların hafızasını oluşturmada etkilidir. Kuşkusuz bellek, uzun zaman öncesine dayanabilen bir toplumun paylaşılan deneyimleri olmakla beraber bugün hala toplumun mevcut normları, davranışları ve inançları üzerinde ekonomik, politik ve sosyal sonuçları olan önemli bir etkiye sahiptir (Dessí, 2008 akt. Puntscher vd., 2014:117). Boşnaklar, gündelik yaşamlarında mekânsal pratikler ile kimliklerini ifade etme sürecine girişmişlerdir. Stavrides (2016) sürgünde inşa edilen kimliklerin yeni tecrübeleri özümsediğini yeni ölçütler keşfettiğini bu nedenle kimliğin kronotopik bir nitelik kazanacağını, sürgündeki kimliğin ötekilikle yüz yüze gelmeye mecbur olduğunu, karşılaşmalar sonucunda kimlikte değişimin yaşanabileceğini fakat tersinin de mümkün olduğunu yani yabancı bir ülkeye giden kişilerin dış dünyaya karşı kimliklerini mühürleyip kapatmaya çalışabileceklerini de belirtir. Stavrides'in kuşkusuz tersi yönde deneyim ifadeleri Boşnaklarda karşılık bulmuştur. Boşnaklar kimliklerini mekânlar üzerinde mühürlemiştir. Dışlanma ve ötekilik süreçleri maddi sınırlardan daha katı mekânlar oluşturmalarını sağlamıştır. Katılığın oluşumunda etkili olan söylemlerden bir diğerini katılımcı sözlerinde vurgulamaktadır:

"Bizlere Tito "nun askerleri, komünistler derlerdi. Türkçe bilmediğimiz için gâvur deniliyordu. Bakıyorlardı biz farklı bir dilde konuşuyoruz, anlamıyorlardı. Boşnakça konuşurduk, hala Boşnakça konuşuyoruz. Camilere girip çıktıkça Müslüman olduğumuzu anladılar. O dönem Türkiye çok cahildi. Cahil kesim bize gâvur derdi. Türkçe bilmesek de anllyorduk. Biz biliyoruz anliyorduk bizde de gâvur gâvurdur. Daha sonra 1992 Bosna Savaşı ve Sirpların yaptı̆̆ı katliamların sadece Müslüman olduğumuz için yapıldı̆̆ını öğrenince bize artık öyle davranmadılar (Erkek, 81).”

Katılımcının ifadelerinden yola çıkarak dönemin Türkiye'si ve Yugoslavya Devleti arasındaki ideolojik farklıı̆ğın halka yansıdığını söylemek mümkündür. Yugoslavya'nın sosyalizm ile yönetilmesi, Boşnakları ideolojik bir damgalamaya uğratmıştır. Birinci nesil göçmenler gündelik hayatlarının her noktasında bu damgaya maruz kalmıştır. Zamanla mahallede yaşayan bireylerle ortak paylaşımlarda bulunmaları, aynı iş yerinde çalışmaları, aynı marketi kullanmaları gibi ortak mekânlar aracılığıyla bireyler birbirlerini daha iyi tanımaya başlamıştır. Özellikle, 1992 Bosna Savaşı ve Srebrenitsa Katliamı gibi olayların medyada sıklıkla yer bulması Boşnakların damgalanma ve örselenme süreçlerini hafifletmiş Boşnaklar, kendilerine karşı daha hoş görülü davranmaya başladıklarını belirtmişlerdir (Bknz. Tacoğlu, vd. 2012). Bu haberlerden sonra Boşnaklar, artık onlar hakkında gavur söyleminden vazgeçildiğini belirtmişlerdir. Bauman (2018: 69) der ki; yeryüzünde tecrit edilmiş ve birbirinden ayrılmış ye- 
reller, küresellerle, göklerden gelen düzenli televizyon yayınları aracılığıyla buluşurlar. Bu karşılaşmanın yankıları tüm yerel sesleri boğup, küresel bir biçimde tekrar yankılanırken yerel duvarlar tarafindan yansıtılır, böylelikle yerel duvarların hapishaneye benzer geçit vermezliği gözler önüne serilir ve pekişir.

Kimliğin bugünkü dinamikliğinin bir diğer kaynağı ise, Boşnakların Türkiye’ye geldikleri zaman isimlerinin ve soy isimlerinin değiştirilmesidir. İstedikleri isimlerin verilmemesi ve soy isimlerinde yapılan değişiklikler Boşnaklar için kimlik sorunlarına yol açmıştır. Boşnaklar da bu duruma karşı sosyal medya hesaplarında, Türkiye'de verilen soy isimlerinin yanı sıra eski soy isimlerini kullanmaya başlamıştır. Bu durum, Boşnak kimliğinin yeni nesilde de farklı kulvarlarda gelişerek korunduğunu bir sonraki nesilde unutulmaya karşı sosyal medya belleğinden yararlanıldı̆̆ını göstermektedir. Katılımc1nın sözleriyle:

"Genelde soy isimlerimizin sonunda "viç” vardl, bu komünizmi çağrıştırdı ̆̆ iç̧in değiş̧tirilmiş. Ailelerimiz karşı çıkmış ama yine de değişstirilmiş. Bizimkiler de buna karşılık mesela Sancak, Bayraktar ve Karadă̆lı gibi soy isimleri almışlar. Hayır, benim soyadımdan kime ne, onu da değiştirdiler. Çocuğuma isim koyacă̆ım neymiş bu Müslüman ismi değilmiş, tartıştık daha sonra oradan bir memur geldi ne oluyor burada? diye bize sordu. Dedim çocuğuma isim koyacă̆ım müsaade etmiyor. O olmasa izin vermeyecekti çocuğuma isim koymama (Erkek, 77)."

Boşnakça konuşuyor olmaları mahallede Türkçe konuşan bireyler ile aralarında kimlik krizi yaşamalarına sebep olmuştur. Boşnakların gidebildikleri en son nokta ise kimlikleri olmuştur. Boşnaklar, her bölgede farklı kimlikler altında ötekileştirilmişlerdir. Bu durum sonucunda tarihlerine, kültürlerine ve dillerine sarılan Boşnaklar gündelik yaşam pratiklerinde her alanda kimliklerini kullanarak, kolektif eylemlerle kimlik bilinci oluşturmuştur. Bu savunmacı tepkiler, tarihsel malzemelerden yeni kültürel kodlar inşa ederek anlamın ve kimliğin kaynakları haline gelmiştir. Ötekilik söylemlerine karşı konumlanan bellek, ötekilik içerisinde çatlamalar yaratarak kimlik duygusunun güçlenmesini sağlamıştır. Yaşanılan bu süreçler Boşnakların kimliklerini mekânsallaştırmalarını, gündelik hayatlarında mekânsal pratiklerle kimliklerini deneyimlemelerini sağlamıştır.

4.4. Ulusötesi Bir Mekânda Kimliğin Sunumu

Ama insanların bir sürü şeyi anımsamalarını nasıl önleyebilirsiniz ki?

Orwell 2019: 269

Bireyler göç ederken mekânlar ve yerler arasındaki bağlarda çözülmeler yaşanır. Yeni mekâna yerleşen bireyler bozulan sosyal yapılarını, yeni iktisadi ve sosyal düzen içerisinde yeniden oluştururlar. Özellikle sosyal süreçler belli bir mekânda oluştuğu için mekândan etkilenirler ve aralarında diyalektik süreçler yaşanır. İçinde bulunduğu mekândan etkilenerek oluşan sosyal süreçler mekânın üretimini yeniden sağlamaktadır. İnsanlar, aktif bir yapıda mekâna müdahalede bulunurlar ve mekânı örgütlerler. Bu süreç, her toplumda farklı karşılık bulur. Mekân, ilişkilerin bir yansımasını sunarken, farklılıkların da üretimini sağlar. Bu süreç bireylerin güç hiyerarşilerine, sermaye türlerine ve belleklerine göre değişmektedir. Sosyal, ekonomik, kültürel sermayeleri ve belleği zengin bir göçmen, kamusal ve özel mekânların görünümünü değiştirerek ev sahibi toplumun yerel ortamına eklemlenebilir. Bu eklemlenme 
sürecinde sermaye, mekânların inşasını sağlarken bellek, mekânları anlama kavuşturarak farklı yerellikler arasında kendi yerel kimliklerini inşa etmelerini sağlar. Bu inşa edilen mekânları, sembollerle donatmak ve adlandırmak mekânı sahiplenmenin en büyük göstergesidir. Bütünüyle bu durum, mekânın hafızasının dışavurumudur. Tüm bu işaretler, mahallede yaşayan grubun zaman içerisindeki deneyimlerini ve mücadelelerini hatırlatarak, mekâna olan bağl1lı̆̆ ve aidiyeti arttırmaktadır. Bu mekânlar hem yaşantılarla hem de bünyesinde barındırmış olduğu nesneler yoluyla bireylerin hafızasını koruyarak kimlik algılarını şekillendirmektedir. Aynı zamanda, yaşayan farklı gruplar arasında bir mekânı adlandırmak, kimliğe referans vermek, kimliklerle müzakere etmeyi ve çeşitli mücadeleler vermeyi gerektirir, bu mücadele mekânı siyasallaştırır ve politik bir kimlik kazandırır. Gündelik hayat içerisinde bu mekânlar, siyasi eylemin yapıldığı bir mekâna dönüşür. Farklı yerelliklerin hayali birlikteliği mekânlarda maddileşir. Bu şekilde ideolojik yapılar gündelik hayatta yeniden üretilir.

Yıldırım Mahallesi, farklı yerelliklerin sergilendiği bir mekândır. Bu mekân, Boşnak kimliği ile özdeşleşerek Boşnak Mahallesi olarak anılmaktadır. Boşnakları diğer kimliklerden ayıran ana faktör ise Boşnaklar inşa edilmiş bir mekâna yerleşmemişlerdir, mekânları birinci nesil göçmenler bir diğer ifadeyle iletişimsel belleğin kolektif bellekleri ile inşa edilmiştir. Halbwach (2017), bir grubun üyelerinin dağıldığında ve yeni fiziksel çevrelerinde onlara terk ettikleri evi ve odaları hatırlatan hiçbir şey bulamadıklarında, uzamda bir arada kalarak bu evi bu odaları akıllarına getirdiklerini ve mekânın grubun izini taşıdığı gibi gruplarında mekânların izlerini taşıdığını belirterek hafıza ve mekân arasındaki ilişkiyi vurgular. Boşnaklar, Yıldırım Mahallesi’nde bir araya gelerek hafızalarında yer alan evlerini yine kolektif hafizları aracılığıyla Yıldırım Mahallesi’nde oluşturmuşlardır. Mahallede oluşturulan her mekân, sokak, kimliğin sembolleri ile donatılarak anlamlandırılmış ve bu sayede aidiyetlik bağı geliştirilmiştir. $\mathrm{Bu}$ aidiyetlik mekânlarda kullanılan sembollerde ve isimlerde kendini sergilemektedir. Mahalleye yerleşen bireylerin ortak deneyimleri bireysel ve kolektif hatırlamayı sağlamak da ortak olmanın bir yolunu oluşturmaktadır. Kolektif hafızada yer alan ortak nesneler gerçeklik ile uyuştuğu sürece Boşnaklar için mahallenin herkese ait bir yere dönüşmesini sağlamaktadır. Mahalle hem benliğin hem de bizliğin ifade edildiği bir mekâna dönüşmüştür. Katılımcının ifadeleri ile:

"Geldiğimizde buralar tarlaydı evimin bahçesinde kendime yetecek kadar sebze ve meyve yetiştiriyordum. Su, elektrik hiçbir şey yoktu buraya geldiğimizde 4 ev vardı benimkisi 6. ev. Evimizin önündeki yolları biz yaptık. İlk önce bodrum ve tek katlı daha sonra zamanla üst katları yaptık ama en fazla 2 katl yaptık 3 katl yapanlar da vardır. Kuyulardan su çıkarlyorduk (Foto 1). Bu kuyudan işte. Baktıkça eski günlerimizi hatırllyoruz. Ben bu kuyuya baktığımda geldiğimiz zamanı hatırlıyorum. Çektiğimiz sıkıntıları, yokluğu, zorluklarımızı hatırlıyorum. Biz buraya kültürümüzü taşıdık, şalvarımızı, dilimizi, böreğimizi. Bakın burası bir Boşnak Mahallesi, burayı biz yaptık (Erkek, 77)."

Bir yer, 'benim yerim' olarak adlandırıldığı andan itibaren, bireyin 'benlik'inin vücut bulduğu, imajının yansıdığı bir yer, daha da önemlisi kendi imgesini gördüğü, kimliğinin dışsallaştığı bir yer haline gelmiş demektir (Bilgin, 2010: 28). Mahallede bulunan geçmiş yaşamın somut deneyim nesneleri, zamanın sınırlarını kaldırarak, gündelik yaşamı dönüştürmekte; burada ve oradalığı, kesintiyi ve başlangıcı bağdaştırmakta, belleği ortak bir düzlemde kurmaktadır. Bu noktada, var olan her nesne ve mekânın her bir parçasına dâhil olan Boşnaklar için mahalle artık Türkiye'de inşa edilen Boşnak kimliğinin bir 
parçasıdır. Bu süreçte, katılımcının hafızasında önemli bir yer tutan su kuyusunun Yıldırım Mahallesi'nde hala varlığını koruması hiç şüphesiz anlamlıdır. Mekânda anıların somut temsilcileri, zihinsel olanın somut gerçekliğini sunmaktadır. Horton ve Kraftl (2012), maddi nesnelerin hatıraların oluşumunda önemli bir yere sahip olduğunu hatıraların sürekli nesnelere eklendiğini bunun bir parçası olarak; hatıraların bedenler, durumlar ve mekânlar yoluyla yoğunluğu ve dokuyu toparladıklarını ifade ederler.

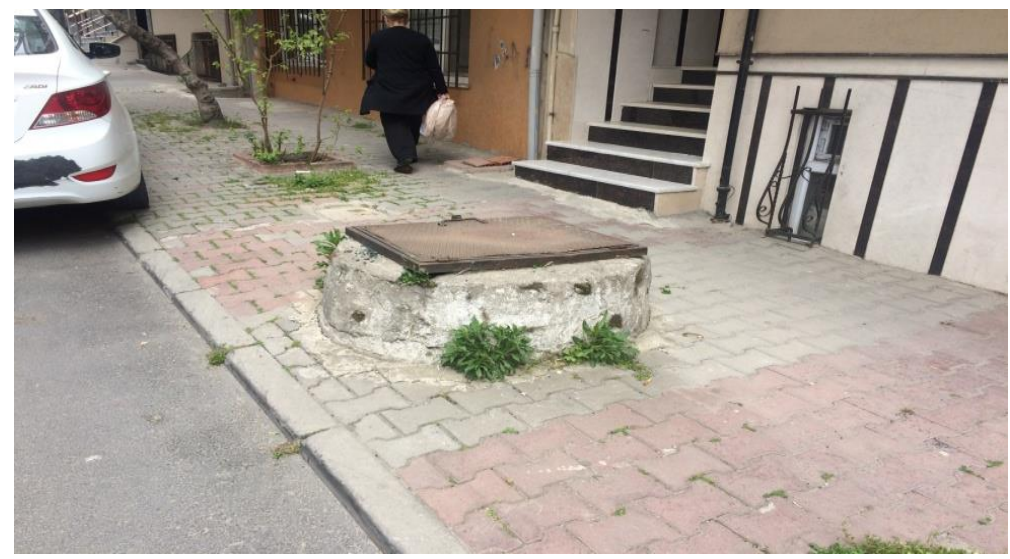

Foto 1. 1960-1965 yılları arasında kullanılan su kuyusu ${ }^{13}$.

Yıldırım Mahallesi'nde bulunan mekânların birçoğu, ait oldukları (içerisinde barındırdıkları) kişilerin kimliği haline gelmiştir (Foto 2). Bu kimlik, herkese açık bir şekilde mekânlar üzerinden sunulmaktadır. Bu sunum, Boşnakların kimlik ve aidiyetlik duygularının mekânın dokusu ile iç içe geçtiğini göstermektedir. Bu birliktelik, yerel topluma ötekiliğinin bir sunumuyken, üyesi olduğu grubun paydaşlarına benliğinin bir sunumudur. Bireyler ile iletişim kurmak yerine mekânlarla iletişim kurulur, bireylere göre mekânların anlatısı değişmektedir. Katılımcının sözleri ile:

"Ben aileye sonradan katıldım. Bu mekânlar mesela hep Sancak ya da Boşnak isimleriyle açılmış. Bu da onların kültürlerine bağlllıklarını gösteriyor. Her şeyi birbirlerine hitap edecek şekilde yaplyorlar. Mekânların isimlerinin böyle olmasının nedeni de bu. Ben de sizdenim. Ben de bir Boşnă̆ım. Siz, bir işletme sahibi ile konuşmadan nereden geldiğini ve kim olduğunu işletmelerin isimleri ile öğrenebilirsiniz (Kadın, 65)."

Katılımc1, mekânsal anlatıya eşlik ederek mekânsal kompozisyonu bozmamıştır. Mekânsal anlatının bir diğer yüzü ise diğer katılımcının sözlerinde aydınlanmaktadır. Gelecek kuşaklarda kültürel belleğin sürdürülmesinde mekânlardan yararlandıklarını bir katılımcı şu sözlerle ortaya koymaktadır:

"Kültürel kimlikler ölmezler veya silinmezler. Yaşandıkça hatırlanır ve kimliği benimsedikçe gelecek nesillere aktarılır. Yaşadığımız kültürle büyüyoruz ve büyüteceğiz gelecek nesli. Bunu da açılan mekânlarda yansıtacă̆ız, konuşmamızda veya çizdiğimiz resimlerde (Odak Grup 1).”

Menşe bölgenin kültürel mimarisi ve sembolik mekanları mahallede bulunan mekanların dış peyzajını etkilemiştir. Özellikle TBSKYD’nin dış peyzajı Mostar Köprüsü şeklindedir (Foto 3). Her iki toplumda Boşnakları temsil eden derneğin mimarisi Bosna'ya olan aidiyetlik duygusunu vurgulamaktadır. Bununla birlikte, derneğin ‘Türkiye Bosna Sancak’ ismini kullanması üç yere aidiyeti 
temsil etmektedir. Kolektif hafiza ile oluşturulan bu temsiller, mahalleye ve her iki topluma aidiyeti arttırmaktadır.
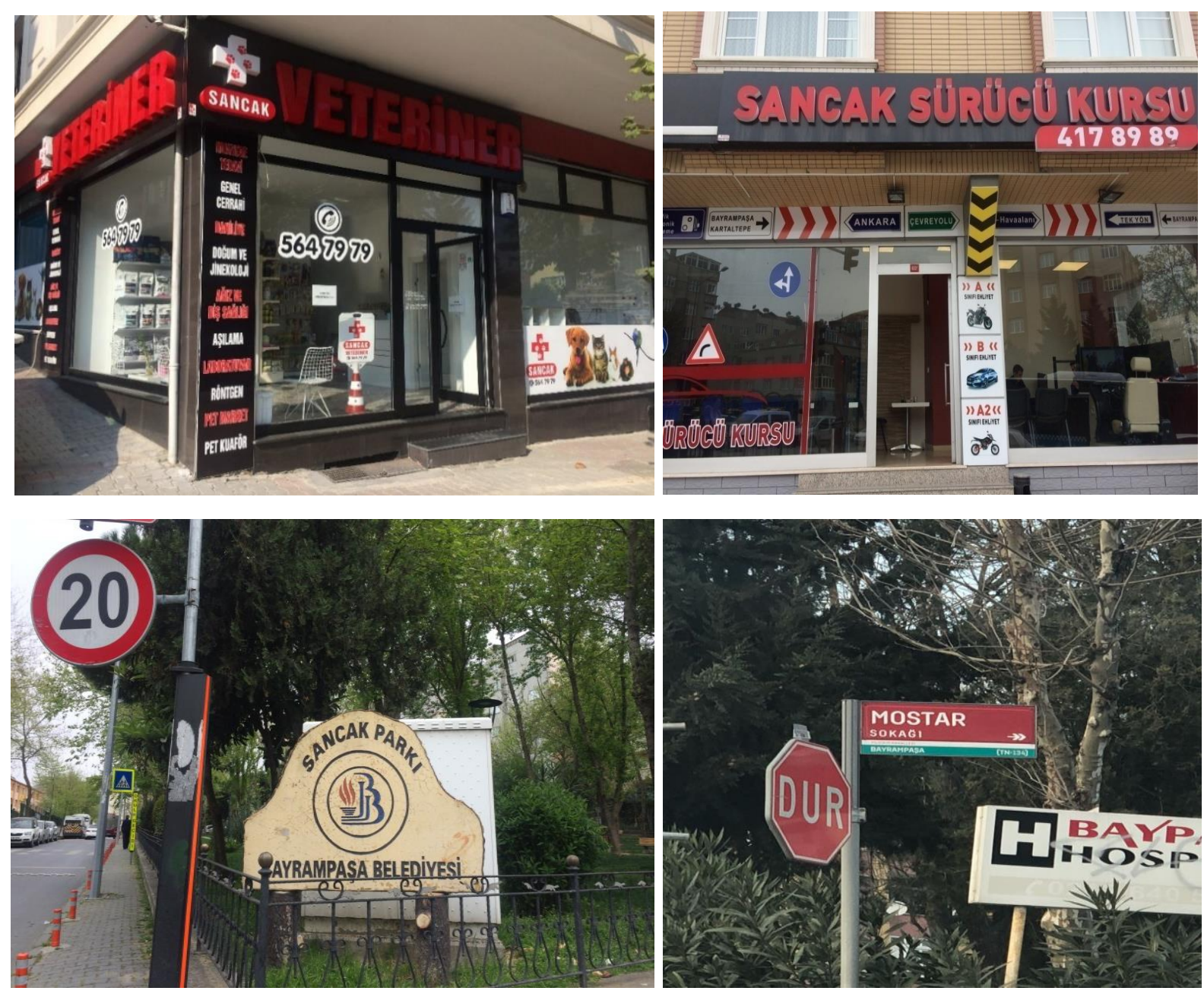

Foto 2. Boşnak kimliğinin kamusal alanda temsilleri. 


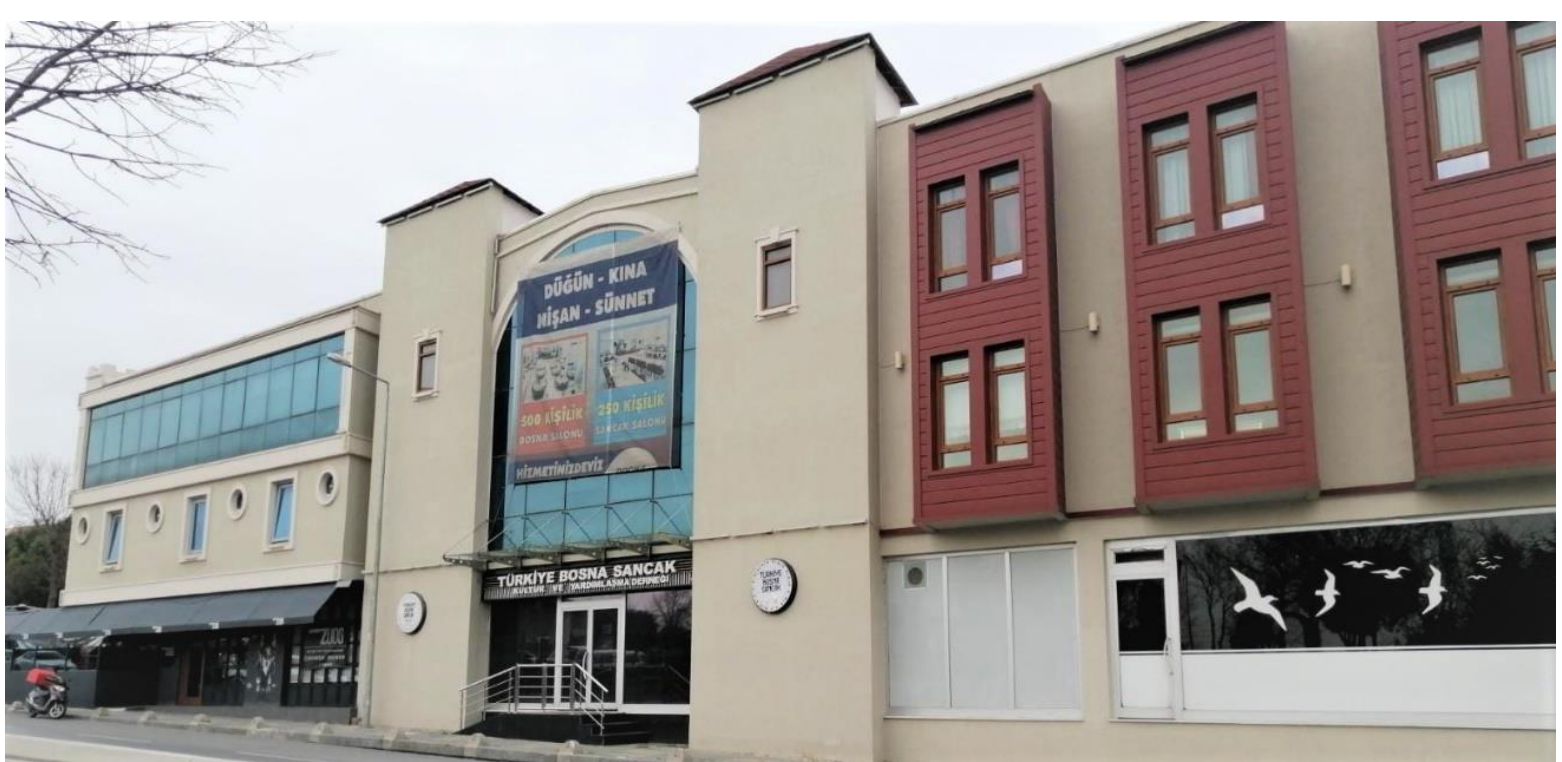

Foto 3: Türkiye Bosna Sancak Kültür ve Yardımlaşma Derneği.

Boşnaklar, kolektif hafizaları ile üretmiş oldukları mekânlarda iki ülkeye karşı besledikleri aidiyet bağlarını sembollerle ifade etmektedir (Foto 4). Bazen bu ifadeler mekânların isimlerinde bazen de mekânların düzenlenişinde kullanılan sembollerde kendini göstermektedir (Foto 5). Mekânların iç yapısı, Bosna ve Sancak bölgesinin bayrağı ile işaretlenmesinin yanısıra fotoğrafları ile de işaretlenmektedir (Foto 6). Aynı zamanda mekânların peyzajında iki ülkeye aidiyetlik semboller ile ifade edilmektedir. Bu işaretler ikili aidiyetliğin de bir sunumudur. Sancak bayrağının renklerini temsil eden saksılar ve kapı süsleri alanda göze çarpmaktadır. Kişisel otomobillerinde Boşnak müziklerini dinlemelerinin yanı sıra araç aksesuarlarının da Sancak bayrağından oluşması dikkat çekicidir. Alanda yaşayanların bazıları arabalarının arka tarafına plakalarının yanına Sancak bayrağı fotoğrafları yapıştırmaktadır. "Ortak dili konuşmanın yanı sıra bayrak gibi, sloganlar gibi ya da bir resim, bir tablo, bir şiir vb. simgeler de göçmen bireyler için ulusaşırı alanda bağlayıcı bir nitelik kazanmakta, ortak kimliğin bir işareti gibi görülmektedir (Yiğittürk Ekiyor, 2017: 233)”. Mekânın, bu işaretler ile donatılması ulusötesi aidiyeti ve kimliği korumaktadır. Boşnaklar için, ortak kimliği referans alan işaretler, varoluşun sembolik göstergesini oluşturmakla birlikte mekânı sahiplenmenin benimdir demenin de bir yoludur. "Bu inşa edilen mekânların, mülkiyeti kendine ait olsun ya da olmasın bir yeri semboller ile işaretlemek, inşa etmek ve böylece anlamlandırmak, o yere hâkim olmanın, kendi iradesine tabi kılmanın, kendi kimliğini vermenin göstergesidir (Bilgin, 2010: 28)". Boşnaklar, kolektif bellekleri ile ürettikleri mekânlarda bulunan semboller ve isimler yoluyla mekânı anlamlandırarak bir aidiyetlik duygusu oluşturmuşlardır. Bugün bu duygu iletişimsel belleğin ürettiği mekânlar ve aktardığı hafıza sayesinde gerçekleşmektedir. 

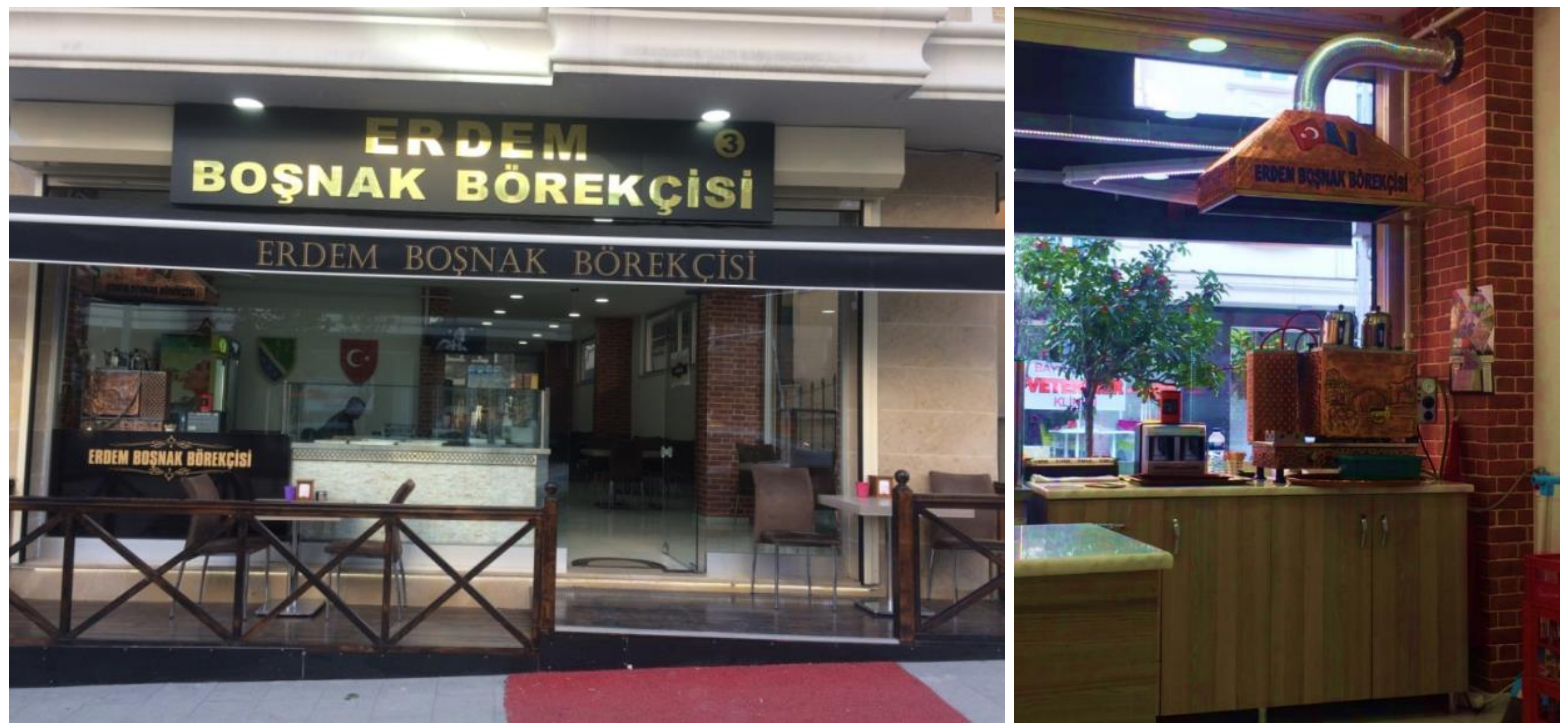

Foto 4. İkili aidiyetliğin mekânda birlikteliği.
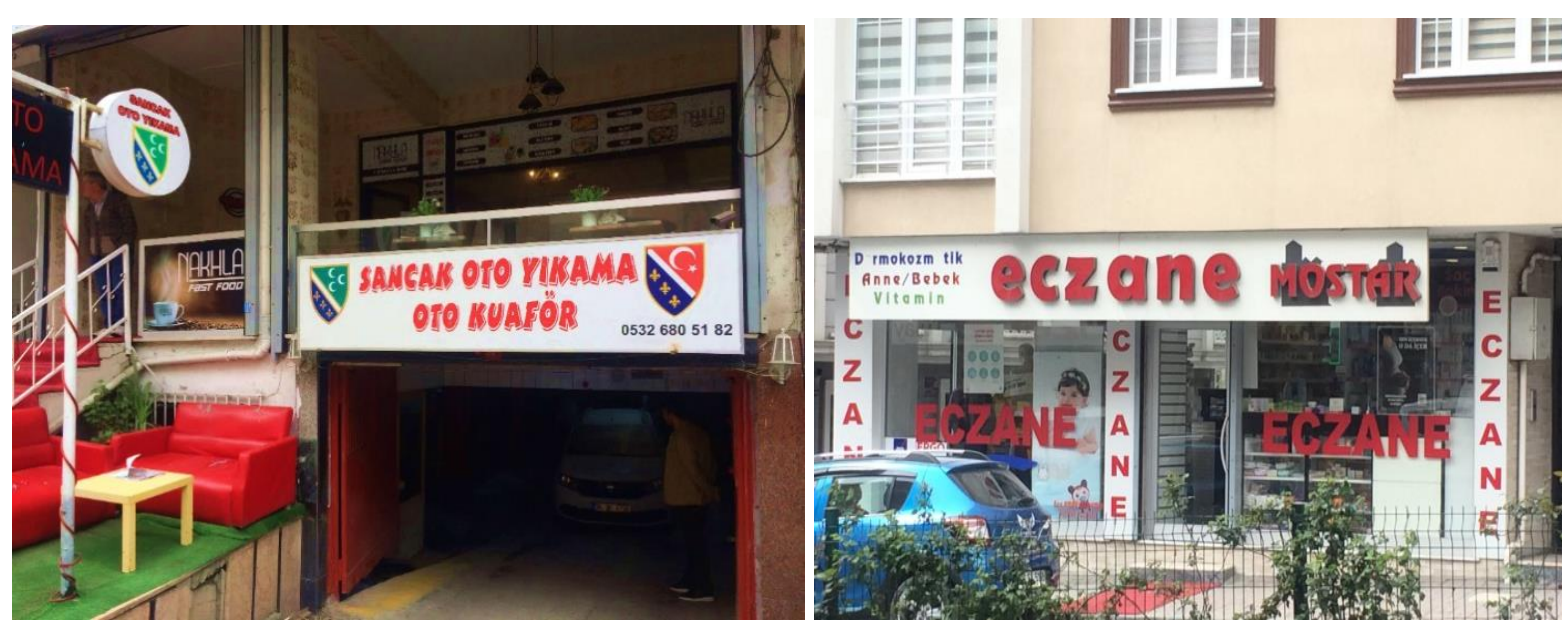

Foto 5. Boşnak kimliğinin kamusal mekânlarda kullanımı.
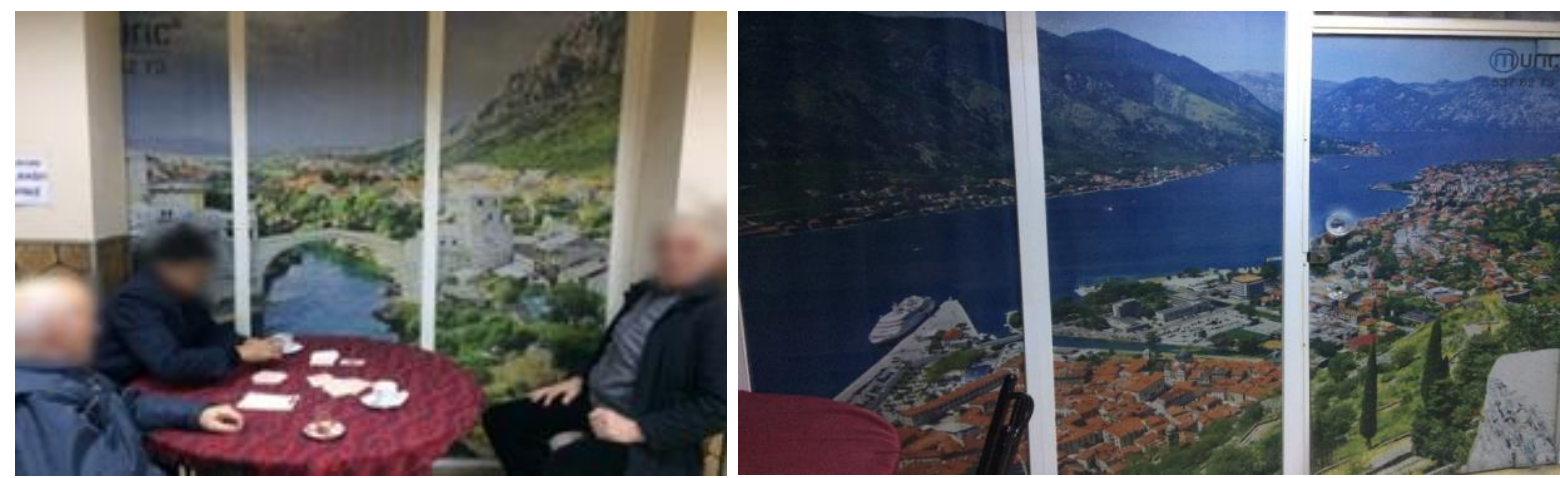

Foto 6. Boşnak kimliğinin iç mekânda kullanımı.

Boşnakların yanı sıra, mahalle'de yaşayan farklı gruplarda kendi kimliklerini kullanarak işletmeler açmıştır. Özellikle Karadeniz Bölgesinden göç eden göçmenlerde işletmelerinde kendi kimliklerini kullanmıştır. Buna karşılık Boşnak olmamalarına rağmen, bazı bireyler işletmelerinde 
Boşnak kimliğini kullanmayı tercih etmiştir (Foto 7). Mekâna o an için sahip olan birey, mekânı Boşnak kimliği üzerinde temellendirmekte, mekâna ötekinin kimliğini vermektedir. Kimlik burada kullanıcısına göre anlamını değiştirmektedir. Boşnaklar için, kimliğin mekândaki anlamı varoluşunun sembolik ifadesiyken, diğer grupların sermaye edinmesini sağlayan bir araca dönüşmüştür. Ayrıca, işletme sahipleri tarafından Novi Pazar'ın kullanılması, farklı grupların Boşnakların tarihine ilgisini göstermektedir. Bu ilgi, ekonomik temelli olsa da artık Boşnaklar ötekilikten sıyrılarak dışlanmanın ötesinde benimsenen bir topluluk haline geldiğini de göstermektedir. Katılımcının açılan mekânlar ile ilgili sözleri:

"Yıldırım Mahallesi'nde işletme açan kişiler bize özgü isimler veriyor. Örneğin, Novi Pazar Gurme'nin sahibi Siirtli, Bosna Mermer'in sahipleri Kastamonulu. Bizleri kendilerine çekmek için bize özgü isimler veriyorlar. Ama biz çok fazla tercih etmiyoruz (Kadın, 72)."

"Yemek yediğimiz restoranlar bizi taniyorlar. Kasap, klyma istediğimiz zaman sorar, Boşnak Böreği için mi diye, bilirler bizi, bir şey istediğimiz zaman hemen bunun için mi diye sorarlar. Biryan-kapama-kuru et ile yaparı. Kasap bunu bilir, kemikli kuru et verir. Pljeskavica köftemiz vardır. Mahalledeki kasaplar artık bu köfteden satıyorlar. Saku vardır, kaymaklı biber turşusu bu turşudan da yapmaya başladılar. Biz onları etkiledik. Bizi bilenler, bize yönelik ürünler satmaya başladılar (Erkek, 84).”
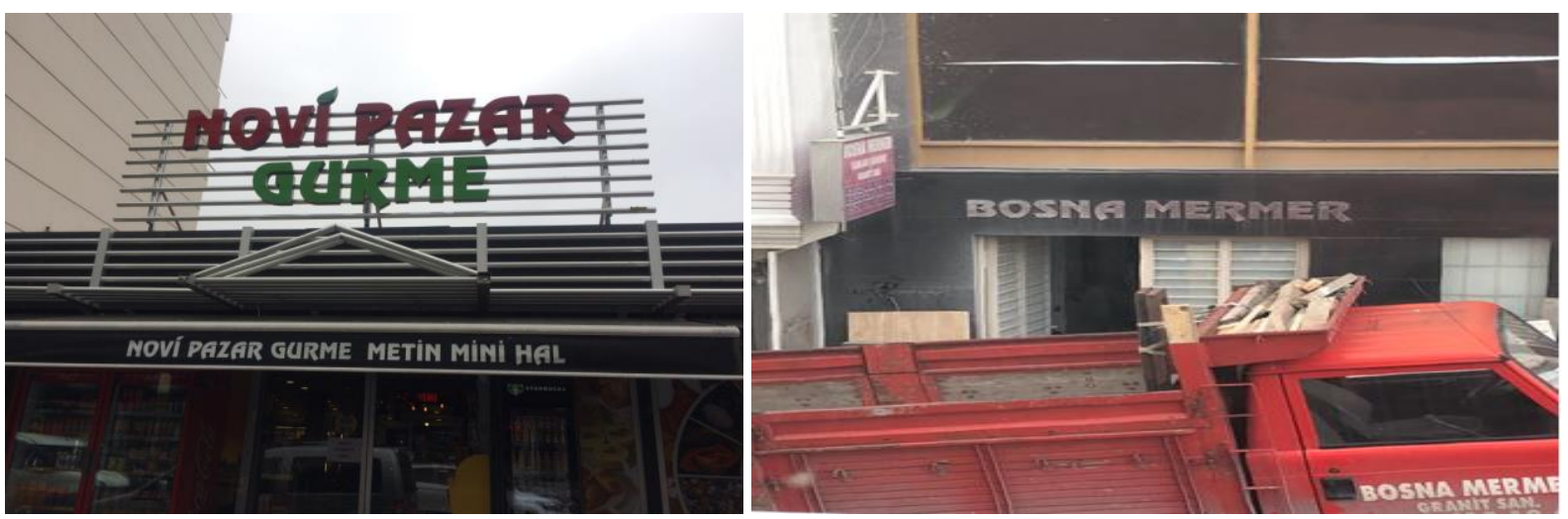

Foto 7. Farklı gruplar tarafından Boşnak kimliğinin kullanıldığ iş̧letmeler.

\section{Sonuç}

1952-1967 yılları arasında Yugoslavya ve Türkiye arasında başlayan göç hareketi, Yugoslavya'nın 1992 yılında dağılmasıyla birlikte Bosna Hersek ve Sancak Bölgesi üzerinden devam etmiştir. Bu göç hareketi sonucunda Türkiye'nin birçok farklı bölgesine Boşnaklar yerleşmiştir. Bu yerlerden biri olan Yıldırım Mahallesi Boşnakların, iki ulus devlet arasında ulusaşırı sosyo-kültürel faaliyetlerde bulundukları bir mekâna dönüşmüştür. Bu mekânın dönüşümünde Bayrampaşa ilçesinin sanayi alanı olarak belirlenmesi ve arazilerin ucuz olması etkili olmuştur. Bu süreçte, mahalleye dış göçün yanı sıra iç göçün yaşanması Boşnakların ötekiliği deneyimlemelerine yol açmıştır. Cumhuriyetin kuruluş yıllarında nüfusun millileştirilmesi yönündeki politikalar için Danış ve Parla (2009) hazmı kolay görülen grupları içerme politikalarıyla el ele gittiğini, makbul olarak kabul edilenleri içererek dışlama stratejisine 
maruz kaldıklarını ve bu makbulluk hiyerarşisinde Balkanlardan gelenlerin ilk sırada yer aldığından söz eder. Boşnaklar, ilk sıraları paylaşıp iktidar tarafından kabul görmelerine rağmen, halk tarafindan kabul görmeleri birtakım sorunlar yaşandıktan sonra olmuştur. Bir diğer ifadeyle, devlet tarafından içerilen gruplar toplum tarafindan dışlanmış, yerel toplum ve göçmenler arasında kabul ve uyum sorunları yaşanmıştır. Bununla birlikte, alanın sanayi alanı olarak belirlenmesi ve arsaların ucuz olması, Boşnakların emek piyasasına dâhil olmasını ve mahallede mülk edinmesini kolaylaştırmıştır. Ayrıca, yerel piyasadan elde edilen sermayelerin yanı sıra yurtdışında çalışan göçmenlerin gönderdiği dövizler/para havaleleri mahallede mülk edinilmesinde etkili olmuştur. Bu süreçte, beşerî sermayeleri gelişen Boşnakların toplum içerisinde statüleri yükselmiş, farklı alanlarda girişimcilik faaliyetlerinde bulunmuşlardır. Ekonomik sermayelerinin gelişmesi ve mahallede turizm acentelerinin kurulması ile birlikte menşe bölgeye ziyaretler artmıştır. Akrabalarını ziyaret eden Boşnaklar, kültürel ürünlerini Yıldırım Mahallesi’ne taşımışlardır. Ayrıca, Türkiye Bosna Sancak Kültür ve Yardımlaşma Derneği’nin kurulmasıyla birlikte Boşnakların hem ev sahibi toplumda hem de Bosna ve Sancak bölgesinde görünürlüğü artmıştır.

Boşnaklar, Yıldırım Mahallesi'nde bir araya gelerek kolektif bellekleri ile mekânları anlama kavuşturmuş, semboller ve isimlendirmeler yoluyla aidiyet bağ geliştirmişlerdir. Bu alan, Boşnakların dillerini ve ritüellerini sürdürmelerini ve iki topluma eş zamanlı katılmalarını sağlamıştır. Bunun yanı sıra, açılan mekânlarda kimliğin kullanılması, mahallenin sembollerle işaretlenerek isimlendirilmesi, mahallede Boşnakların güçlendiğinin bir göstergesidir. McDowell'ın (2009) da ifade ettiği gibi, kamusal alandaki yerler hiçbir zaman apolitik değildir. Bu yerler Boşnakların, ötekilikten sıyrılarak kendi kimliklerini meşrulaştırdığı ev sahibi topluma kendilerini kabul ettirdikleri bir mekâna dönüşmüştür. Aynı zamanda bu mekân, menşe toplum ile ilişkilerin sürdürüldüğü bir mekâna da dönüşmüştür. $\mathrm{Bu}$ ilişkilerin sürdürülmesini ve kimliğin yeniden inşa edilmesini bellekleri sağlamıştır. Bellek mekânsal bir bağlama oturtularak, gündelik yaşam içerisinde sosyal ve mekânsal pratikler ile Boşnakların hafizasını, kimliğini ve iki ülkeye aidiyet bağlarını üretmektedir. Bu durum, iki ülke arasında bağların güçlenmesini, ulusötesi sosyo-kültürel ağların gelişmesini sağlamıştır. Sembollerle işaretlenen bu mekânların; bir sonraki neslin, iki ülkeye aidiyet bilincinin gelişmesinde etkili olması beklenmektedir. Yıldırım Mahallesi'nin Boşnaklar için anlamını Halbwachs'ın (2017) sözleriyle yinelemek gerekirse; bu mekânın her bir veçhesinin, her ayrıntısının yalnızca grup üyelerinin anlayabileceği bir anlamı vardır, çünkü uzamın grup tarafından işgal edilen her bölümü, kendi topluluklarının yapısının ve ömrünün pek çok farklı yönüne tekabül eder, en azından toplulukta daha istikrarlı olmuş olanlara.

\section{Notlar}

1. Yugoslavya Sosyalist Federal Cumhuriyeti 1992 yılında dağılmıştır. Araştırmada sözü edilen Boşnak göçmenlerin geldiği ülke günümüzde Bosna-Hersek ve Sancak Bölgesidir.

2. 16.02.2021 tarihinde http://www.bayrampasa.gov.tr/tarihce adresinden alınd1.

3. Haritanın yapımında ArcGIS 10.8 programı kullanılmıştır.

4. Çalışmada, derinlemesine görüşme ve odak grup görüşmesi yapılan örneklem grubunu birinci nesil göçmenler oluşturmaktadır. Yıldırım Mahallesi’nin birinci nesil göçmenler tarafından oluşturulması, gönüllü göçmen olarak gelmeleri, Demokrat Parti tarafından ekonomik desteğin sağlanmaması nedeniyle 192-1967 yılları arasında gelen göçmenler ele alınmıştır. 1877 1878 Osmanlı Rus Savaşı, Balkan Savaşı ve Birinci Dünya Savaşı'nda Balkanlardan birçok göçmen gelmiştir. Bu çalışmada, Birinci nesil göçmen kavramı, 1952-1967 yılları arasında Yıldırım Mahallesine yerleşen ve mahallenin inşa sürecinde bulunan bireyleri kapsamaktadır. Daha önce gelen göçmenler, Osmanlı'nın birçok farklı bölgesine yerleştirilmiş, tarım ve hayvancılık 
faaliyetlerini yürütmeleri amacıyla toprak ve hayvan temin edilmiştir. Mahalle’nin gelişim sürecinde daha önce göç eden ve farklı bölgelerde yaşayan Boşnaklar da gelmiştir. Sahada bu konu ile ilgili görüşmeler yapılsa da çalışmada yer verilmemiştir. 5. İletişimsel bellek, yakın geçmişe ilişkin anıları kapsar. Bunlar kişinin çağdaşları ile paylaştığı anılardır. Bunun en tipik örneği kuşağa özgü bellektir. Bu bellek tarihi olarak grupla bağlantılıdır, zamanla oluşur ve zamanla yok olur; daha açık ifade edersek taşıyıcıları ile sınırlıdır (Assman, 2018: 58).

6. 19.11.2017 tarihinde Beyaz TV'de yayınlanan Beyaz Futbol programında Rasim Ozan Kütahyalı'nın Boşnaklar ile ilgili söylediği sözler karşısında Boşnaklar Kamuoyu açıklaması yapmıştır (https://www.bsavakfi.org/kiniyoruz). Birçok alanda bu durumla ilgili yaşadıkları rahatsızlığı paylaşmışlardır.

7. Araştırma sorularımız; 1.Yıldırım Mahallesi'ni neden tercih ettiniz? Sizin için anlamı nedir? 1.1. Yıldırım Mahallesi'nden önce farklı şehirlerde/İlçelerde ikamet ettiniz mi? 1.2. Yıldırım Mahallesi’ne yerleşirken kimlerde yardım aldınız? 1.3. Yıldırım Mahallesi’nde yerleştiğiniz dönem hangi sorunlar ile karşılaştınız? 1.4. Yıldırım Mahallesi'nde yerleştiğinizde hangi işlerde çalıştınız? 2. Yıldırım Mahallesi'ne katkılarınız nelerdir? 3.Yıldırım Mahallesi’nde bulunan mekânların sizin için anlamı nedir? 4. Yıldırım Mahallesi’nde işletmelerde, caddelerde, park ve okullarda yaygın olarak Boşnak kimliği kullanılıyor. Kimliğinizi kullanmanızın sizin için anlamı nedir? 5. Yıldırım Mahallesi'nin bugünkü sizin için taşıdığı anlam nedir? 6. Mahallede ne gibi kültürel faaliyetler de bulunuyorsunuz? Kültürel faaliyetlerinizi açıklar mısınız? 7. Bosna ve Sancak bölgesinde kültürel faaliyetler de bulunuyor musunuz? Kültürel faaliyetlerinizi açıklar mısınız? 8. Bosna ve Sancak bölgesini yılda kaç kez ziyaret ediyorsunuz? Ziyaret etme nedenlerinizi açıklar mısınız? 9. Derneğin, faaliyetlerini açıklar mısınız? Faaliyetlere katılıyor musunuz? Derneğin size sağladığı avantajlar nelerdir?

8. Özgür Baklacıoğlu (2010: 491-492-493), Türkiye dış politikasında, 16 Mart 1953 tarihli Split Centilmenlik Antlaşmasıyla ilgili herhangi bir bilgiye rastlanmadığını, yaşanılan göçü; Menderes iktidarı ile Tito yönetimi arasında Türkiye tarafından tek yönlü göç vizesi verilmesi kararının alındığını belirtmektedir. 1969 yılında yürürlüğe giren tazminat antlaşmasında yer alan hükümlerde herhangi bir anlaşmadan söz edilmeyerek sadece 13 Temmuz 1956 tarihinin esas alınmasının, göçün 28 Şubat 1953 tarihinde Ankara'da imzalanan Türkiye Cumhuriyeti, Yunanistan Krallığı ve Yugoslavya Federatif Halk Cumhuriyeti arasında Dostluk ve İş birliği Antlaşması ile ilgili görüşmelerde müzakere edilip karara bağlanmış olabileceğini belirtir. Ayrıca, sahada yapılan görüşmelerde, katılımcıların hepsi gönüllü göç antlaşmasıyla geldiklerini bu nedenle devletten maddi bir yardım alamadıklarını belirtmişlerdir. Ayrıca yapılan çalışmalarda, 1953 antlaşmasının 1938 yılında imzalanan ama uygulanmayan antlaşma olduğu çalışmalarda belirtilmektedir (Özgür Baklacıoğlu, 2010; Celep, 2019; Erken, 2018). T.C. Cumhurbaşkanlığ Devlet Arşiv Başkanlığı Sistemi'nde bu antlaşma ile ilgili bir bilgi bulunamadı. Fakat birkaç göçmenin, serbest göçmen olarak geldiği ve vatandaşlığa kabul edildiğine dair Türkiye Cumhuriyeti Cumhurbaşkanlığı Devlet Arşivleri Başkanlığı Cumhuriyet Arşivi (BCA), Toprak İskân Genel Müdürlüğü, Muhacirin Fonu ve Başbakanlık, Kararlar Daire Başkanlığı Fonu’nda dilekçeler mevcuttur.

9. Yugoslavya'dan Türkiye'ye gelenler arasında birçok grubun olduğu belirtilmektedir. Göçmenler, etnik temelli bir tanımlama yerine Müslüman olup olmamasına göre kayıt altına alınmıştır. Bu nedenle etnik temelli bir ayrım yapmak mümkün değildir (Kirişçi, 1995: 69-70).

10. Yapılan bazı çalışmalar arasında gönüllü göç antlaşması ile Türkiye'ye gelen Boşnaklar için devlet tarafından bir iskân politikası uygulanmadığı belirtilmiştir. Bazı çalışmalarda ise, 1953-1957 yılları arasında Türkiye'ye gelen göçmenlere, devlet tarafından uygulanan politikalar doğrultusunda kamplarda barınma, yemek, kira yardımı sağlandığı, 5 yıl vergi muafiyeti uygulandığı, özellikle çiftçi ailelere tohumluk gibi yardımların yapıldığı, bu yardımların iskanlı göçmen statüsünde kabul edilen Bulgaristan göçmenleri için öngörülen yardımların, serbest göçmen statüsünde olan Yugoslavya göçmenleri için bazı bölgelerde geçerli tutulduğu belirtilir (Özgür Baklacıoğlu, 2010, Bayakır, 1998). Katılımcılar arasında devlet tarafından yerleştirildiğini belirtenler olduğu gibi kendilerinin yerleştiklerini ifade edenler de olmuştur.

11. Birinci nesil Boşnakların mahalleye yerleşmeleri; İzmir, Samsun, Giresun, Ordu, Çanakkale, Tekirdağ, Bursa, Edirne, Kocaeli, Sakarya, Kırklareli, Sivas illerinde yaşayan Boşnakları da mahalleye çekmiştir. Günümüzde Yıldırım Mahallesi’ne Türkiye başta olmak üzere Sancak ve Bosna'nın birçok bölgesinden Boşnaklar gelmektedir. Menşe bölgede yaşayanlar için, Yıldırım Mahallesi, Türkiye'deki Sancak ve Bosna olarak bilinmektedir. Türkiye'de yaşayan Boşnaklar için Müslümanlığını ve Boşnak kimliğini rahatça yaşayabildikleri Sancak ve Bosna olarak ifade edilmektedir.

12. Boşnakların yerleştiği Rami, Taşlıtarla ve Yıldırım Mahallesi günümüzde farklı ilçe sınırları içerisinde yer almaktadır. Taşlıtarla 1958'e kadar Eyüp'ün Rami Bucağı'na bağlı olan Küçükköy'ün bir mahallesiydi. 1963 yılında Taşlıtarla merkezli Gaziosmanpaşa ilçesi kuruldu (16.02.2021 tarihinde https://www.gaziosmanpasa.bel.tr/det/124/ilce-tarihi adresinden alındı). 
Rami günümüzde hala Eyüp ilçesi sınırları içerisinde bulunmaktadır. 1990 yılında Bayrampaşa Eyüp ilçesinden ayrılmıştır (16.02.2021 tarihinde http://www.bayrampasa.gov.tr/tarihce adresinden alınd1).

13. Çalışmada yer alan fotoğraflar araştırmacıya aittir.

\section{Teșekkür ve Bilgilendirme}

Bu çalışmadaki değerli katkıları için hakemlere teşekkür ederiz. 
To cite: Çetinkaya, S.C., Göközkut, B. (2021). The Process of Creation with the Bosnian Collective Memory of a Transnational Space and Spatial Presentation of Identity: İstanbul- Yıldırım District, Coğrafi Bilimler Dergisi/ Turkish Journal of Geographical Sciences. 19(1). 61-91. doi: 10.33688/ aucbd.836348

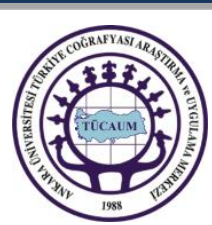

Coğrafi Bilimler Dergisi

Turkish Journal of Geographical Sciences

e-ISSN:1308-9765

\title{
The Process of Creation with the Bosnian Collective Memory of a Transnational Space and Spatial Presentation of Identity: İstanbul- Yıldırım District
}

\author{
Sibel Can Çetinkaya*a, Burcu Göközkut ${ }^{\mathrm{b}}$
}

\section{EXTENDED ABSTRACT}

\section{Introduction}

This study focuses on an identity space produced by Bosniaks' collective memory who emigrated to Turkey from Yugoslavia between 1952 and 1967. In this context, the Ylldırım Neighbourhood in the Bayrampasa district of Istanbul and Bosniaks who played a significant role in shaping this neighbourhood were examined. Bosniaks engage in socio-cultural activities by transforming this area into a transnational social space with transnational networks between two nation-states. Therefore, the study's main purpose is to question what/how identity is represented in the spaces produced with Bosniak collective memory in Yıldırım Neighbourhood. Studies on immigrants living in the district (Bozkurt, 2012; Celep, 2019; Davutoğlu, 2010; Dural, 2016; Erman, 2019; Eseler, 2016; Güler, 2013; Sözer Dabanlığlu, 2018; Tekinkaya, 2015; Yanardağ, 2009; Yıldız, 2019) did not discuss the relationship of collective memory with space in maintaining Bosniak identity. This study tried to show that the spaces produced by immigrants' collective memory contributed to the maintenance of identity and the development of the bond of belonging.

\section{Transnational Spaces and Collective Memory}

The transnational theory is an important theoretical framework in international migration literature, progressed rapidly towards the end of the 1990s (Al-Ali et al., 2001). Transnational is expressed as the process of building social spaces where they connect their countries of origin and settled countries and use multiple identities (Glick- Schiller et al., 1992; Guarnizo, 1997). In this process, as the literature of transnational migration expanded, the concept of "transnational community" began to be used frequently (Bruneau, 2010). Transnational immigrants/communities are migrants whose daily lives transcend national borders and develop social, economic, political, and religious relations between at least two countries (Bowen, 2004; Castles, 2002; Faist, 2000; Guarnizo, 1997; Glick -Schiller et al., 1992; Kivisto, 2001; Levitt, 1998, 2003; Özgür, 2018; Portes, 2000; Şimşek, 2019). Transnational social spaces are vibrant and established societies; developing various networks between at least two countries and generating new types of capital using their economic, political and cultural capital; where belonging and identity are maintained, and new belonging, class, identity, and policies are developed; they are arenas

\footnotetext{
*Sorumlu Yazar/Corresponding Author: sibelcancetinkayaa@gmail.com

a Afyon Kocatepe University, , Graduate School of Social Sciences, Afyonkarahisar/Turkey, https://orcid. org/0000 -00025931-1925.

b Afyon Kocatepe University, Geography Department, Afyonkarahisar/Turkey, https://orcid.org/0000-0002-2214-8327.
} 
where political actions are carried out, demographics and gender relations are changed, and various structures of power are embedded (Bruneau, 2010; Collyer ve King, 2014; Crang et al., 2003; Dannecker, 2005; Faist, 2000, 2003, 2012; Fouron and Glick-Schiller, 2001; Levitt and Glick-Schiller, 2004; Levitt and Jaworsky, 2007; Özgür, 2018; Şimşek, 2019; Voigt-Graf, 2004). In transnational spaces, collective memory, which can be expressed as a group identity, has an essential share in maintaining the bonds of belonging with the society of origin and forming a bond of belonging with the host community. According to Mills (2014:46), one of the most critical elements in the process of imagining which people themselves share a particular identity is the reproduction of a collective memory of the past.

\section{Methodology}

Qualitative research shows a research feature that the knowledge of being social is compiled from people's expression and narrative (Kümbetoğlu, 2019: 38). Therefore, using the qualitative research method in the study, the relations between migration, memory and space were tried to be understood based on individuals' narratives. For this purpose, field research was carried out in Istanbul province, Bayrampasa district, Yıldırım Neighbourhood in January, February, April and September 2018. In the research area, 20 participants who were first-generation immigrants were interviewed using snowball sampling. After the sample group was determined, a focus group interview was conducted with 4 women and 3 men and two groups of men consisting of 6 and 7 people using the semi-structured interview form in Turkish. The age range of the group interviewed in depth is $63-84$, and the age range of the two groups interviewed is 58-76. The findings were analyzed using the method of descriptive analysis.

\section{Result}

The Agreement of Friendship and Cooperation between Turkey and Yugoslavia, known as the 1953 Treaty, was instrumental in the migration of Bosniaks to Turkey (Ağanoğlu, 2013; Celep, 2019; Çalışkan, 2019; Çavuşoğlu, 2007, 2014; Erken, 2018; Özgür Baklacıoğlu, 2010; Zorbay, 2017). The agreement facilitated the crossing of borders for Bosniaks while establishing a mechanism of action for the next generation to participate in relocation practices. In this way, most Bosniaks who came as free immigrants emigrated to different parts of Turkey. Also, individuals living in different regions of Turkey and Istanbul and have migrated to the neighbourhood. Gaziosmanpasa, Eyüp and Bayrampasa districts; Taşlıtarla, Küçükköy, Rami and Yıldırım Neighbourhood are a few of these areas. With the continuation of the migration flow, the settlements' limits are expanded and new residential areas were created. Y1ldirım Neighbourhood has expanded its borders with migrants from different regions of Yugoslavia and Turkey. Bosniaks formed a homogeneous community in the area where they settled in the target area. Over time, the government's designation of the Bayrampasa district as an industrial area allowed different identities to be seen in the space, and the neighbourhood became the threshold of otherness. Stavrides (2016) stated that thresholds point to the transformation processes of social identities. Heterogeneous identities that hovered thresholds were instrumental in the production of this homogeneous identity. As a result of these encounters, Bosniaks, called gâvur (slang for non-Muslims), became the neighbourhood's marginalized group. Bosniaks who settled in the neighbourhood have accumulated capital by working in various business areas. Multi-story houses were built in such a way that large families could live on the land taken. The coexistence of Bosniaks has been effective in maintaining the culture by strengthening their cooperation and solidarity in everyday life. 
Bosniaks stayed together in their daily lives, transforming the space into a place of identity and belonging where they maintained their identity and continued their rituals. In this area, they organize commemorative events, seminars on migration and their identity, entertainment and cultural days. In their daily lives, they speak both Bosnian and Turkish, read the news of the two countries, listen to their music and maintain their food culture. They wear Bosnian shalwar on their special days. These have now become a component of the daily lives of Bosniaks. This situation shows that the culture of the two communities shapes the everyday life of Bosniaks. This union intertwines in spaces produced with collective memory, making sense of their lives and strengthening feelings of belonging and identity.

Bosniaks gathered in Yildırım Neighbourhood and created their homes in this area through their collective memories. Each place created in the neighbourhood was made sense by equipping it with symbols of identity and thus, the bond of belonging was developed. This belonging is manifested in the symbols and names used in the spaces. Collective memory was provided with the common experiences of the individuals who settled in the neighbourhood. Inside and outside the spaces, the Bosnia and Sandzak Region flags are used; photos of these areas are also used. In addition, the common experiences of the individuals who settled in the neighbourhood constitute a way of this partnership by providing individual and collective remembering. Bosniaks created a sense of belonging by making sense of the space through symbols and names in the spaces they produced with their collective memories. Today, this feeling is realized thanks to the spaces produced by the communicative memory and the memory it conveys. In this way, belonging to the neighbourhood and both communities increases. Today, this feeling is realized thanks to the spaces produced by communicative memory and the memory it conveys.

When a place is called 'my place,' it means that it has become a place where the 'self' of the individual is embodied, where his image is reflected, and, more importantly, where he sees his image and identity is externalized (Bilgin, 2010: 28). Concrete experience objects of past life in the neighbourhood transform everyday life by removing time boundaries; reconciling here and there, the interruption and the beginning, establishing memory on a common area. At this point, for Bosniaks who are involved in every existing object and space, the neighbourhood is now part of the Bosniak identity built in Turkey.

\section{Conclusions}

The migration movement between Yugoslavia and Turkey between 1952 and 1967 continued through Bosnia and Herzegovina and the Sandzak Region, with Yugoslavia's dissolution in 1992. As a result of this migration movement, Bosniaks settled in many different regions of Turkey. Y1ldirım Neighbourhood, one of these places, has become a space where Bosniaks engage in transnational sociocultural activities between two nation-states. In this space's transformation, the Bayrampasa district's determination as an industrial area and the land's cheapness were effective. In this process, the external migration to the neighbourhood and the internal migration led Bosniaks to experience otherness. Besides, the area's designation as an industrial area and the land's cheapness made it easier for Bosniaks to get involved in the labor market and acquire property in the neighbourhood. The capital obtained from the local market and foreign currency/money transfers sent by migrants working abroad were instrumental in acquiring property in the neighbourhood. In this process, Bosniaks' status, whose human capital has developed, has increased in society and they have engaged in entrepreneurship activities in different fields. With the development of their economic capital and the establishment of tourism agencies in the neighbourhood, visits to the origin region have increased. Bosniaks who visited their relatives moved their cultural products to Ylldirım Neighbourhood. In addition, with the establishment 
of the Bosnian Sandzak Cultural and Relief Association of Turkey, Bosniaks visibility has increased both in the host community and in Bosnia and the Sandzak Region.

Bosniaks came together in Yıldırım Neighbourhood to understand collective memories and spaces and developed a bond of belonging through symbols and terminology. This area allowed Bosniaks to continue their language and rituals and participate in two communities simultaneously. Placing memory in a spatial context produces the memory, identity, and belonging ties of Bosniaks with social and spatial practices in everyday life. This has strengthened relations between the two countries and led to the development of transnational socio-cultural networks.

\section{Referanslar/References}

Ağanoğlu, H.Y. (2013). Osmanlı'dan Cumhuriyet'e Balkanların Makus Talihi: Göç. İstanbul: İz Yayıncılık.

Al-Ali, N., Black, R., Koser, K. (2001). The limits to 'transnationalism': Bosnian and Eritrean refugees in Europe as emerging transnational communities. Ethnic and Racial Studies, 24(4), 578-600. doi: 10.1080/01419870120049798

Assman, J. (2018). Kültürel Bellek. İstanbul: Ayrıntı Yayınları.

Bauman, Z. (2018). Küreselleşme: Toplumsal Sonuçları. İstanbul: Ayrıntı Yayınları.

Bayakır, H. (1998). Bayrampaşa'da Sanayi. İstanbul Üniversitesi, Sosyal Bilimler Enstitüsü, Yayımlanmamış Yüksek Lisans Tezi. İstanbul. https://tez.yok.gov.tr/UlusalTezMerkezi/176370 adresinden edinilmiştir.

Bauböck, R. (2003). Towards a political theory of migrant transnationalism. International Migration Review, 37(3), 700-723. doi: 10.1111/j.1747-7379.2003.tb00155.x

Bilgin, N. (2013). Tarih ve Kolektif Bellek. İstanbul: Bağlam Yayıncılık.

Bilgin, N. (2010). Sosyal düşüncede kent kimliği. IDEALKENT, 2 (3), 20-47. 26.10 .2019 tarihinde https://dergipark.org.tr/ en/pub/idealkent/issue/36633/417042 adresinden alınd1.

Bowen, J. R. (2004). Beyond migration: Islam as a transnational public space. Journal of Ethnic and Migration Studies, 30(5), 879-894. doi:10.1080/1369183042000245598

Boyer, C. (1996). The city of collective memory. Cambridge: MIT Press. akt: Harvey, D. (2015). Kozmopolitlik ve Özgürlük Coğrafyaları. İstanbul: İstanbul Bilgi Üniversitesi Yayınları.

Bozkurt, N. (2012). Cumhuriyet Dönemi'nde Yugoslavya'dan Marmara Bölgesi'ne Göçler ve Mekânsal Etkileri. Marmara Üniversitesi, Türkiyat Araştırmaları Enstitüsü, Yayımlanmamış Yüksek Lisans Tezi, İstanbul. 06.10.2017 tarihinde https://tez.yok.gov.tr/UlusalTezMerkezi/331160 adresinden edinilmiştir.

Bruneau, M. (2010). Diasporas, transnational spaces and communities. R.Bauböck ve T. Faist (Ed.), Diaspora and Transnationalism: Concepts, Theories and Methods içinde (35-50). Amsterdam: Amsterdam University Press.

Castells, M. (2006). Enformasyon Çağl: Ekonomi, Toplum ve Kültür (İkinci Cilt): Kimliğin Gücü, (2. Bask1). İstanbul: İstanbul Bilgi Üniversitesi Yayınları.

Castles, S. (2002). Migration and community formation under conditions of globalization. International Migration Review, 36(4), 1143-1168. doi:10.1111/j.1747-7379.2002.tb00121.x

Castles, S. (2010). Understanding global migration: a social transformation perspective. Journal of Ethnic and Migration Studies, 36(10), 1565-1586. doi:10.1080/1369183x.2010.489381

Castles, S., Miller, M. J. (2008). Göçler Çă̆ı Modern Dünyada Uluslararası Göç Hareketleri. İstanbul: İstanbul Bilgi Üniversitesi Yayınları.

Celep, A. (2019). Cumhuriyet Sonrası Türkiye’ye Göç Eden Boşnakların Yeni Kimlik İnşası. Marmara Üniversitesi, Sosyal Bilimler Enstitüsü, Yayımlanmamış Yüksek Lisans Tezi. İstanbul. https://tez.yok.gov.tr/UlusalTezMerkezi/598495 adresinden edinilmiştir.

Cohen, J. H. (2019). Göçmen dövizlerinin etkileri ve göç: kuramsal önermeler ve firsatlar. Göç Dergisi, 6(2), 119-150. doi: 10.33182/gd.v6i2.663

Collyer, M., King, R. (2014). Producing transnational space: international migration and the extra-territorial reach of state power. Progress in Human Geography, 39(2), 185-204. doi:10.1177/0309132514521479

Crang, P., Dwyer, C., Jackson, P. (2003). Transnationalism and the spaces of commodity culture. Progress in Human Geography, 27(4), 438-456. doi:10.1191/0309132503ph443oa

Cuba, L., Hummon, D. M. (1993). A place to call home: identification with dwelling, community, and region. The Sociological Quarterly, 34 (1), 111-131. doi:10.1111/j.1533-8525.1993.tb00133.x 
Çalışkan, B. (2019). İstanbul'da Yaşayan Bir Grup Arnavut Kökenli Göçmenin Göç Deneyimleri Ve Vatandaşlık Algıları. Marmara Üniversitesi. Sosyal Bilimler Enstitüsü, Yayımlanmamış Yüksek Lisans Tezi, İstanbul. https://tez.yok.gov.tr/UlusalTezMerkezi/550921 adresinden edinilmiştir.

Çavuşoğlu, H. (2007). Yugoslavya-Makedonya topraklarından Türkiye’ye göçler ve nedenleri. Bilig Türk Dünyası Sosyal Bilimler Dergisi, 41, 123-154. 12.11. 2017 tarihinde http://bilig.yesevi.edu.tr/sayi-41-bahar-039-07 adresinden alınd1.

Çavuşoğlu, H. (2014). Yugoslavya-Makedonya'dan Türkiye'ye 1952-67 "Kitlesel" göçü ve Bursa'daki göçmen kesimi. Karadeniz Araştırmalarl, $\quad 10, \quad 107-147 . \quad 12.10 .2017 \quad$ tarihinde http://karamdergisi.com/Makaleler/851985571_cavusoglu.pdf adresinden edinilmiştir.

Danış, D., Parla, A. (2009). Nafile soydaşlık: Irak ve Bulgaristan Türkleri örneğinde göçmen, dernek ve devlet. Toplum ve Bilim, 114, 131-158. 16.02.2019 tarihinde http://research.sabanciuniv.edu/26757/ adresinden alınd1.

Dannecker, P. (2005). Transnational migration and the transformation of gender relations: the case of Bangladeshi labour migrants. Current Sociology, 53(4), 655-674. doi:10.1177/0011392105052720

Davutoğlu, A. (2010). Boşnak Göçmenlerde Aile İçi Ekonomik Sosyalleşme: İstanbul Yıldırım Mahallesi Örneği. İstanbul Üniversitesi, Sosyal Bilimler Enstitüsü, Yayımlanmamış Yüksek Lisans Tezi, İstanbul. https://tez.yok.gov.tr/UlusalTezMerkezi/271026 adresinden edinilmiştir.

Dessí, R. (2008). Collective memory, cultural transmission, and investments. The American Economic Review. 98: 534-560. akt. Puntscher, S., Hauser, C., Pichler, K., Tappeiner, G. (2014). Social capital and collective memory: A Complex Relationship. Kyklos, 67 (1), 116-132. doi:10.1111/kykl.12046

Dural, A. B. (2016). Bayrampaşa ilçesinin sosyo-kültürel dokusunun oluşumunda toplumsal hafiza-Balkan göçmenlerinin etkisi. II. Uluslararası Türk Kültür Coğrafyasında Eğitim ve Sosyal Bilimler Sempozyumu / 5-7 Mayıs 2016 / Nizip. 568-590.

Ekici, S., Tuncel, G. (2015). Göç ve insan. Birey ve Toplum Sosyal Bilimler Dergisi, 5 (1), 9-22. doi:10.20493/bt.71783

Erken, A. (2018). Demokrat Parti dönemi Türkiye-Yugoslavya ilișkileri ve Serbest Göç Mutabakatı. Insan ve Toplum Bilimleri Araştırmaları Dergisi, 7 (2), 937-954. doi:10.15869/itobiad.399472

Erman, S. (2019). Autobiographical Memories of First-And Second-Generation Balkan and Place Attachment to The Homeland. Boğaziçi Üniversitesi, Sosyal Bilimler Enstitüsü, Yayımlanmamış Yüksek Lisans, İstanbul. https://tez.yok.gov.tr/UlusalTezMerkezi/582427 adresinden edinilmiştir.

Eseler, B. (2016). Rumeli Göçmenlerinin Siyasal Katılımı ve Davranışları "Bayrampaşa İlçesi Örneği". Trakya Üniversitesi, Sosyal Bilimler Enstitüsü, Yayımlanmamış Yüksek Lisans Tezi, Edirne. https://tez.yok.gov.tr/UlusalTezMerkezi/438469 adresinden edinilmiştir.

Faist, T. (2000). Transnationalization in international migration: implications for the study of citizenship and culture. Ethnic and Racial Studies, 23(2), 189-222. doi:10.1080/014198700329024

Faist, T. (2003). Sınırları aşmak devlet aşırı alan konsepti. Thomas Faist (Ed.), Devletaşırı Alan: Almanya ve Türkiye arasında siyaset, ticaret ve kültür içinde (15-56). İstanbul: Bağlam Yayıncılık.

Faist, T. (2012). Transnational migration. G. Ritzer (Ed.), Wiley-Blackwell Encyclopedia of Globalization, içinde, doi:10.10 02/9780470670590.wbeog910

Fouron, G., Glick-Schiller, N. (2001). All in the family: gender, transnational migration, and the nation-state. Identities, 7(4), 539-582. doi:10.1080/1070289x.2001.9962678

Geray, C. (2019). Türkiye'den ve Türkiye'ye Göçler ve Göçmenlerin İskanı 1923-1961. Tunceli: Kalın Yayıncılık.

Glick-Schiller, N., Basch, L., Blanc-Szanton, C. (1992). Transnationalism: a new analytic framework for understanding migration. Annals of the New York Academy of Sciences, 645, 1-24. doi: 10.1111/j.1749-6632.1992.tb33484.x

Glick-Schiller, N., Çağlar, A. (2009) Towards a comparative theory of locality in migration studies: migrant incorporation and city scale. Journal of Ethnic and Migration Studies, 35(2), 177-202. doi: 10.1080/13691830802586179

Glick-Schiller, N. (2003). The centrality of ethnography in the study of transnational migration. N.Foner (Ed.) American Arrival: Anthropology Engages The New Immigration içinde (s.99-128), Santa Fe: School Am. Res. Press. akt. Özkul, D. (2012). Ulus-ötesi göç: Uluslararası göç yazınında yeni bir paradigma, S.G. Ihlamur-Öner, N.S. Şirin-Öner (Eds.), Küreselleşme Çağında Göç: Kavramlar Tartışmalar içinde (s.483-500), İstanbul: İletişim Yayınları.

Guarnizo L.E. (1997). The emergence of a transnational social formation and the mirage of return migration among dominican transmigrants. Identities, 4(2), 281-322. doi: 10.1080/1070289X.1997.9962591

Guarnizo, L. E. (2003). The economics of transnational living. International Migration Review, 37(3), 666-699. doi: 10.111 1/j.1747-7379.2003.tb00154.x

Güler, Ö. R. (2013). İstanbul İlçelerindeki Demografik Yapının, Yerel Yönetimlerin Kültür Politikaları Üzerindeki Etkileri: Bayrampaşa Belediyesi Örneği. İstanbul Bilgi Üniversitesi, Sosyal Bilimler Enstitüsü, Yayımlanmamış Yüksek Lisans Tezi, İstanbul. https://tez.yok.gov.tr/UlusalTezMerkezi/333962 adresinden edinilmiştir. 
Halbwachs, M. (2017). Kolektif Hafiza. İstanbul: Heretik Yayıncılık.

Harvey, D. (2015). Kozmopolitlik ve Özgürlük Coğrafyaları. İstanbul: İstanbul Bilgi Üniversitesi Yayınları.

Honig, B. (2019). Exploring the intersection of transnational, ethnic, and migration entrepreneurship. Journal of Ethnic and Migration Studies, 1-17. doi:10.1080/1369183x.2018.1559993

Hopkins, N., Dixon, J. (2006). Space, place, and identity: issues for political psychology. Political Psychology, 27 (2), $173-$ 185. doi:10.1111/j.1467-9221.2006.00001.x

Horton J., Kraftl, P. (2012). Clearing out a cupboard: memory, materiality and transitions. Owain Jones and Joanne GardeHansen (Ed.), Geography and Memory içinde (25-44). London: Palgrave Macmillan Memory Studies. doi: $10.1057 / 9781137284075 \_2$

Kirişçi, K. (1995). Post second World War immigration from Balkan Countries to Turkey. New Perspectives on Turkey, 12 , 61-77. doi:10.1017/s089663460000114x

Kivisto, P. (2001). Theorizing transnational immigration: a critical review of current efforts. Ethnic and Racial Studies, 24(4), 549-577. doi: 10.1080/01419870120049789

Kümbetoğlu, B. (2019). Sosyolojide ve Antropolojide Niteliksel Yöntem ve Araştırma. İstanbul: Bağlam Yayıncılık.

Lefebvre, H. (2015). Mekânın Üretimi. İstanbul: Sel Yayınları.

Levitt, P. (1998). Social remittances: migration driven local-level forms of cultural diffusion. International Migration Review, 32(4), 926-948. doi:10.1177/019791839803200404

Levitt, P. (2003). You know, Abraham was really the first immigrant: religion and transnational migration. International Migration Review, 37(3),847 873. doi:10.1111/j.1747-7379.2003.tb00160.x

Levitt, P., Glick-Schiller, N. (2004). Conceptualizing simultaneity: a transnational social field perspective on society. International Migration Review, 38(3), 1002-1039. doi:10.1111/j.1747-7379.2004.tb00227.x

Levitt, P., Jaworsky, B.N. (2007). Transnational migration studies: past developments and future trends. Annual Review of Sociology, 33, 129-156. doi:10.1146/annurcvjoc33.040406.131816

Levitt, P., Lamba-Nieves, D. (2011). Social remittances revisited. Journal of Ethnic and Migration Studies, 37(1), 1-22. doi:10.1080/1369183X.2011.521361

Ley, D. (2004). Transnational spaces and everyday lives. Transactions of the Institute of British Geographers, 29(2), 151-164. doi:10.1111/j.0020-2754.2004.00122.x

Massey, D. S., Goldring, L., Durand, J. (1994). Continuities in transnational migration: an analysis of nineteen Mexican communities. American Journal of Sociology, 99(6), 1492-1533. doi:10.1086/230452

McDowell, S. (2009). Memory. R. Kitchin ve N. Thrift, (Ed.), International Encyclopedia of Human Geography içinde (5963). Amsterdam: Elsevier Online.

Mills, A. (2014). Hafizanın Sokakları: İstanbul'da Peyzaj, Hoşgörü ve Ulusal Kimlik. İstanbul: Koç Üniversitesi Yayınları.

Nkrumah, A. (2017). Immigrants' transnational entrepreneurial activities: the case of Ghanaian immigrants in Canada. Journal of International Migration and Integration, 19(1), 195-211. doi:10.1007/s12134-017-0535-Z

Nora, P. (2006). Hafiza Mekânları. Ankara: Dost Kitabevi Yayınları.

Orwell, G. (2019). 1984. İstanbul: Can Yayınları.

Özgür, E. M. (2018). Küresel göçün sosyo-mekânsallığı: ulusötesi mekânlar / yerelötesi yerler, topluluklar ve kimlikler. Coğrafi Bilimler Dergisi, 16 (1), 1-35. doi:10.1501/Cogbil_0000000189

Özgür Baklacıŏlu N. (2010). Dış Politika ve Göç: Yugoslavya'dan Türkiye’ye Göçlerde Arnavutlar (1920-1990). İstanbul: Derin Yayınları.

Portes, A. (2000). Immigration and the metropolis: reflections on urban history. Journal of International Migration and Integration, $1(2), 153-175$. doi: $10.1007 / \mathrm{s} 12134-000-1000-\mathrm{x}$

Schad, T. (2015). The rediscovery of the Balkans? A Bosniak-Turkish figuration in the Third Space between Istanbul and Sarajevo. Working Paper No: 8, Istanbul Bilgi University, European Insitute Jean Monnet Centre of Excellence, (8), 1-28. 13.11.2019 tarihinde https://eu.bilgi.edu.tr/media/files/WORKING_PAPER_8-041215.pdf adresinden alındi.

Stavrides, S. (2016). Kentsel Heterotopya. İstanbul: Sel Yayıncılık.

Sözer Dabanlığlu, S. (2018). The Themes in The Narratives Transmitted to The Third Generation Bosniac Immigrants of Sandzak Region. İstanbul Bilgi Üniversitesi, Sosyal Bilimler Enstitüsü, Yayımlanmamış Yüksek Lisans Tezi, İstanbul. https://tez.yok.gov.tr/UlusalTezMerkezi/507481 adresinden edinilmiştir.

Şimşek, D. (2019). İstanbul'daki Afrikalı göçmenlerin ulusötesi sosyal alanlarının entegrasyon süreçlerine etkisi. Öneri Dergisi, 14 (52), 216-235. doi:10.14783/maruoneri.594943 
Tacoğlu, T., P., Arıkan, G., Sağır, A. (2012). Boşnak göçmenlerde göç ve kültürel kimlik ilişkisi: Fevziye Köyü örneği. Turkish Studies, 7(1), 1941-1965, doi:10.7827/TurkishStudies.2908

Tekeli, İ. (2010). Mekânsal ve Toplumsal Olanın Bilgi Bilimi Yazıları. İstanbul: Tarih Vakfı Yurt Yayınları.

Tekinkaya, E. (2015). Göç ve Etnik Ekonomi: İstanbul Bayrampaşa'da Boşnak Göçmenler. Marmara Üniversitesi, Sosyal Bilimler Enstitüsü. Yayımlanmamış Yüksek Lisans Tezi, İstanbul. https://tez.yok.gov.tr/UlusalTezMerkezi/ 396893 adresinden edinilmiştir.

Tilley, C. (1994). A Phenomenology of landscape, places, paths and monuments. Oxford, England: Berg. akt. Bader, G. (2018). Space, place, and memory in holloway by Robert Macfarlane, Stanley Donwood, and Dan Richards. Space and Culture. 1-8 doi: $10.1177 / 1206331218773658$

Türkiye Cumhuriyeti Cumhurbaşkanlığı Devlet Arşivleri Başkanlığı Cumhuriyet Arşivi (BCA), Toprak İskân Genel Müdürlüğü, Muhacirin Fonu. 13.11.1959 tarihli belge.

Türkiye Cumhuriyeti Cumhurbaşkanlığı Devlet Arşivleri Başkanlığı Cumhuriyet Arşivi (BCA), Başbakanlık, Kararlar Daire Başkanlığı Fonu. 10.03.1956 tarihli belge.

Türkiye İstatistik Kurumu (TÜİK, 2020). Adrese Dayal1 Nüfus Kayıt Sistemi Sonuçları.16.02.2021 tarihinde https://data.tuik.gov.tr/Bulten/Index?p=Adrese-Dayali-Nufus-Kayit-Sistemi-Sonuclari-2020-37210 adresinden alınd1.

Vertovec, S. (2004). Migrant transnationalism and modes of transformation. International Migration Review, 38(3), 970-1001. doi:10.1111/j.1747-7379.2004.tb00226.x

Vertovec, S. (2001). Transnationalism and identity. Journal of Ethnic and Migration Studies, 27(4), 573-582. doi:10.1080/ 13691830120090386

Voigt-Graf, C. (2004). Towards a geography of transnational spaces: Indian transnational communities in Australia. Global Networks, 4(1), 25-49. doi:10.1111/j.1471-0374.2004.00079.x.

Yanardağ, P. (2009). The Epidemic, The Prison House and The Global City Belonging and Identity in Bayrampaşa. Boğaziçi Üniversitesi. Sosyal Bilimler Enstitüsü, Yayımlanmamış Yüksek Lisans Tezi, İstanbul. https://tez.yok.gov.tr/UlusalTezMerkezi/257183 adresinden edinilmiştir.

Yazgan, P. (2016). Hareketlilikte kimlik inşasına yönelik analitik bir çerçeve. Göç Dergisi, 3(2).282-296. doi:10.33182/gd. v3i2.583

Yıldırım, E. (2017). Bilginin Sosyolojisi. İstanbul: Marmara Belediyeler Birliği Kültür Yayınları.

Yıldız, S. (2019). İstanbul - Bayrampaşa'da Yaşayan Balkan Göçmenlerinin Sosyal Uyumu ve Kente Katılımlarının Íncelenmesi. Marmara Üniversitesi, Sosyal Bilimler Enstitüsü, Yayımlanmamış Yüksek Lisans Tezi, İstanbul. https://tez.yok.gov.tr/UlusalTezMerkezi/560687 adresinden edinilmiştir.

Yiğittürk Ekiyor, E., (2017). Ulusaşırı Göç ve Toplumsal Alanda Sosyal Ağlar: ABD’de Yaşayan Türkler Üzerine Bir Araştırma. Gazi Üniversitesi, Sosyal Bilimler Enstitüsü. Yayımlanmamış Doktora Tezi. Ankara. https://tez.yok.gov.tr/UlusalTezMerkezi/48322 adresinden edinilmiştir.

Zaim, S. (1957). Son Yugoslav muhacirleri hakkında rapor. İstanbul Üniversitesi İktisat Fakültesi Mecmuası, 19 (1-4), 435 448. 13.11.2017 tarihinde https://dergipark.org.tr/tr/pub/iuifm/issue/879/9748 adresinden alınd1.

Zorbay, T. (2017). 1950’ler Türk dış politikasında göç meselesi Yugoslavya'dan Türkiye’ye Serbest Göç ve Köprülü/Titoveles ilçesi Örneği. Karabük Üniversitesi Sosyal Bilimler Enstitüsü Dergisi, 7 (1), 318-335. doi: 10.14230/joiss335 